\title{
Article
}

\section{Personality traits, consumer animosity, and foreign product avoidance: The moderating role of individual cultural characteristics}

Leonidou, Leonidas, Kvasova, Olga, Christodoulides, Paul and Tokar, Sergii

Available at http://clok.uclan.ac.uk/26451/

Leonidou, Leonidas, Kvasova, Olga, Christodoulides, Paul and Tokar, Sergii (2019) Personality traits, consumer animosity, and foreign product avoidance: The moderating role of individual cultural characteristics. Journal of International Marketing . ISSN 1069-031X

It is advisable to refer to the publisher's version if you intend to cite from the work. 10.1177\%2F1069031X19834936

For more information about UCLan's research in this area go to http://www.uclan.ac.uk/researchgroups/ and search for <name of research Group>.

For information about Research generally at UCLan please go to http://www.uclan.ac.uk/research/

All outputs in CLoK are protected by Intellectual Property Rights law, including Copyright law. Copyright, IPR and Moral Rights for the works on this site are retained by the individual authors and/or other copyright owners. Terms and conditions for use of this material are defined in the policies page. 


\title{
Personality Traits, Consumer Animosity, and Foreign Product Avoidance: The Moderating Role of Individual Cultural Characteristics
}

\begin{abstract}
Although personality and cultural traits were found to be important predictors or moderators of consumer attitudes and behavior, their relationship to consumer animosity has not yet been studied. This article reports the findings of a study conducted among 606 Ukrainian consumers, aiming to identify personality drivers and behavioral outcomes of consumer animosity, as well as the moderating role of cultural characteristics. Structural equation modeling revealed that extraversion and conscientiousness have a negative effect on consumer animosity, while neuroticism and openness are positively associated with this feeling. However, no significant relationship was observed between animosity and agreeableness. In turn, consumer animosity was found to influence product avoidance, with this association becoming stronger in the case of consumers with higher levels of power distance, uncertainty avoidance, collectivism, and masculinity. The study also showed that male and educated consumers are more likely to harbor animosity toward a hostility-evoking country, while age and income had no control effect on animosity. Several implications for theory and practice are derived from the study findings, and directions for future research are provided.
\end{abstract}

Keywords: consumer animosity; personality; cultural orientation; product avoidance. 


\section{INTRODUCTION}

The firm's international business performance can seriously suffer as a consequence of consumer negative sentiments, attributed to past and/or current offensive incidents between the home country and the target country (Maher and Mady 2010). Klein, Ettenson, and Morris (1998) were the first to relate conflicts between nations to consumers' purchasing behavior, such as boycotts. These scholars introduced the concept of consumer animosity, which they defined as 'remnants of antipathy related to previous or ongoing military, political or economic events' (Klein, Ettenson, and Morris 1998, p. 90). In particular, they showed empirically that the animosity of Chinese consumers toward Japan, caused by the Nanjing massacre in 1937, had a negative effect on their propensity to buy Japanese products. Following Klein, Ettenson, and Morris (1998) research, many other investigations of consumer animosity have been conducted over the last two decades (Papadopoulos, Banna, and Murphy 2017).

Despite sizeable research on animosity-provoking factors, such as group responsibility (Maher and Mady 2010), perceived personal economic hardship (Huang, Phau, and Lin 2010), and different social attributes (Shoham et al. 2006), the effect of personality on consumer antipathy toward foreign goods has never been tested. Meanwhile, just as previous scholars examined alternative antecedents of consumer animosity, the evolvement of Trait theory revealed that another crucial predictor of human attitudes and behavior is personality (Hirsh and Dolderman 2007). In fact, personality has recently become an important factor in marketing research and is consistently used to explain consumer behavior in various settings (Bosnjak et al. 2007; Westjohn, Singh and Magnusson 2012; Thompson and Prendergast 2015). In a similar vein, although the role of cultural orientations has been largely overlooked by prior animosity studies (with the exception of Han (2017)), culture was found to be an important driver of 
consumer behavior in other marketing contexts (Mooij and Hofstede 2011; Gürhan-Canli, SarialAbi, and Hayran 2018). For example, Lin and Kalwani (2018) reported that cultural orientations influence electronic word-of-mouth signaling and screening, while Yeniyurt and Townsend (2003) found a strong association between consumer cultural characteristics and new product acceptance.

Although previous research provided hints that personality and culture can shape consumer sentiments, no attempt has so far been made to simultaneously examine the role of these two characteristics of one's identity. This considerably limits our understanding of the consumer animosity phenomenon, since various other social attributes, such as patriotism (Ishii 2009), nationalism (Shoham et al. 2006), and cosmopolitanism (Park and Yoon 2017), that were examined by past studies, exist in parallel to consumer animosity, and therefore cannot be regarded as universal drivers of consumer antipathy (Han 2017). In comparison to such social attributes, personality and culture are more fundamental factors, and their knowledge can help international marketing managers: (a) to acquire a more holistic picture about consumer animosity and make more informed choices about suitable target groups in foreign markets; (b) to devise more focused strategies to counter the negative effects of animosity in certain countries; and (c) to understand in more depth and breadth the various dimensions of consumer animosity and their outcomes in the context of ongoing hostilities between countries (Gineikiene and Diamantopoulos 2017; Shoham 2006).

In light of these gaps, this study aims to identify: (a) the effect of personality traits on consumer animosity, using the well-validated 'Big Five' personality taxonomy (McCrae and Costa 1985); (b) the impact of consumer animosity on foreign product avoidance; and (c) the moderating effect of various cultural orientations on the link between consumer animosity and 
product avoidance. In particular, we examine consumer animosity within the context of the current hostility of Ukrainian consumers toward Russia. Russia and Ukraine are often referred to as 'Slavic brothers', mainly because they both belong to the Eastern Slavic ethnic group, share the same Christian Orthodox religion, and their history is strongly interconnected (Jakubanecs, Supphellen, and Thorbjørnsen 2005). However, following the Ukrainian revolution of 2014 (also known as the 'Euromaidan Revolution'), and the subsequent incorporation of the Crimea peninsula into the Russian Federation, these culturally close 'brothers' have been turned into enemies. Although Crimea's incorporation into Russia was admitted to be 'illegal annexation' by the United Nations, the Russian side considered it as a 'restoration of historical justice' (because in 1954, for no apparent reason, Crimea (mainly populated by ethnic Russians) was transferred as a gift to the Ukrainian Republic by the central government of the then Soviet Union). Further to these developments, the Eastern regions of Ukraine (where the majority of the population are pro-Russian) began to demand their independence, and, as a result, a serious armed conflict has erupted, causing many deaths and much destruction.

Our study contributes to the pertinent literature of consumer animosity in three different ways. First, we focus on the relationship between the 'Big Five' personality traits (i.e., agreeableness, extraversion, conscientiousness, neuroticism, and openness) and consumer animosity, thus providing an alternative theoretical explanation of how an individual's psychological factors can shape hostile feelings toward foreign goods. Personality is one of the most fundamental factors affecting one's attitudes and behaviors, which, surprisingly, was largely neglected by extant animosity studies. This has made the existing knowledge on the subject relatively incomplete, and perhaps to some extent misleading. We partially addressed 
this gap by empirically proving that personality and consumer negative sentiments are closely related.

Second, our study explores the moderating effect of an individual's cultural orientations on the link between consumer animosity and unwillingness to buy products from a hostile country. This further augments our understanding of the consumer animosity phenomenon based on Hofstede's (2001) dimensions, namely power distance, uncertainty avoidance, individualism, and masculinity. In addition, unlike the majority of previous international marketing studies that viewed the role of cultural differences at the aggregate country level (e. g., Griffith, Yalcinkaya, and Rubera 2014; Pick and Eisend 2016; Tang 2017), we adopt the individual-level approach to culture, since there is strong evidence (e.g., Yoo and Donthu 2005) that consumers within one country are also culturally distinct. This could provide a more precise picture of consumers' sensitivity to confrontation between their home country and a foreign country, which will in turn affect their purchasing behavior.

Third, we take the position that consumer animosity is a complex construct, which comprises multiple dimensions. While many previous studies (e.g., Klein 2002; Ma et al. 2012; Nijssen and Douglas 2004) have used the predetermined two-dimensional domain of animosity, based on military and economic hostility between nations, within the context of our study, we introduce two additional, relatively unexplored dimensions, that is, political and social, which are equally important in order to gain a comprehensive picture of the subject. Also, unlike past research, this study investigates animosity in the context of an ongoing conflict, rather than negative past events. We believe that this provides a deeper insight into the nature of consumer antipathy toward foreign goods, since fresh memories about inter-country conflicts offer a better re- 
flection of consumer negative sentiments and their effect on purchasing behaviors (Gineikiene and Diamantopoulos 2017).

The remainder of this article is organized as follows: the next section provides an overview of the pertinent literature on consumer animosity. This is followed by an explanation of the Social Identity Theory, Realistic Group Conflict Theory, and Self-categorization Theory, which are the guiding theories of our study. Subsequently, we present the conceptual model and develop the research hypotheses. The research method adopted for the purposes of this study is then explained. The next section analyzes the data collected and tests the research hypotheses. The final sections discuss the research findings and draw conclusions, offer theoretical and managerial implications, and propose avenues for further research.

\section{PREVIOUS RESEARCH}

The studies of Klein, Ettenson, and Morris (1998) and Klein and Ettenson (1999) were the first to establish the construct of consumer animosity and distinguish it from the already existing construct of ethnocentrism introduced by Shimp and Sharma (1987). These two seminal studies were followed by dozens of other investigations of consumer animosity that took various directions (see Appendix I for a summary of these studies). However, despite the wealth of knowledge provided by extant literature on consumer animosity, it is too diverse, unprogrammatic, and fragmented, sometimes yielding inconsistent results.

\section{Dimensions, types, and scope of consumer animosity}

Scholars in the field have identified different dimensions of consumer animosity. The pioneering study of Klein, Ettenson, and Morris (1998) assumed that consumer animosity is founded on mil- 
itary and economic issues, and many subsequent investigations were built exclusively on these two dimensions (e.g., Ang et al. 2004; Nijssen and Douglas 2004; Shin 2001). However, more recent studies posited that animosity is not only related to economic hardship or war actions, but could also be embedded in matters associated with mentality and religion (Maher and Mady 2010; Riefler and Diamantopoulos 2007) or politics (Funk et al. 2010). Following this line of research, Nes, Yelker, and Silkoset (2012) suggested that animosity is a four-dimensional construct encompassing war, economic, political, and social components.

There have been several attempts in the past to provide typologies of consumer animosity. For example, Jung et al. (2002) and Ang et al. (2004) distinguish between stable (i.e., accumulated over a relatively long period of time and stemming from past negative events) and situational (i.e., associated with a specific circumstance) animosity, as well as between personal (i.e., arising from personal unpleasant experiences with a country and/or its people) and national (i.e., related to perceived damage that the home country suffered from the foreign country) animosity. Also, Gineikiene and Diamantopoulos (2017) examined consumer animosity in historically connected markets and reported different behavioral responses to negative past events (e.g., nostalgia offsetting the effects of animosity) and current/recent events (e.g., animosity overshadowing nostalgia).

A few studies applied the animosity concept with a different scope. For example, Funk et al. (2010) and Cheah et al. (2016) researched animosity in the context of hybrid products and reported the negative effects of consumer antipathy on willingness to buy such products. Also, Alden et al. (2013) examined animosity at the level of companies/brands, rather than countries, and looked at the association between global company animosity and consumer global brand attitude. Heinberg (2017) widened the scope of animosity from one country to a group of 
countries and concluded that outbreaks of animosity against the West increase Chinese consumers' willingness to buy local brands.

\section{Causes of and influences on consumer animosity}

Several studies examined the factors that precede consumer animosity. For instance, Huang, Phau, and Lin (2010) found that perceived personal economic hardship and the normative influence of consumers' reference groups positively affect animosity beliefs. The role of susceptibility to normative influence in forming consumer hostility was also confirmed by more recent studies (e.g., Park and Yoon 2017). In addition, Hoffmann, Mai, and Smirnova (2011) tried to develop a universal measurement of consumer animosity and argued that three drivers threat, antithetical political attitudes, and negative personal experiences - mediate the influence of specific causes on general animosity. Further, Maher and Mady (2010) reported a strong positive effect of group responsibility on animosity beliefs.

A number of scholars investigated the link between animosity and various social attributes, such as patriotism (Ganideh and Eladee 2018; Ishii 2009), exclusionism (Ishii 2009), dogmatism (Shoham et al. 2006), nationalism (Ganideh and Eladee 2018; Shoham et al. 2006), internationalism (Ganideh and Eladee, 2018; Ishii 2009; Shoham et al. 2006), and cosmopolitanism (Park and Yoon 2017). In general, their studies indicated that patriotism, dogmatism, nationalism, and exclusionism enhance consumer animosity, whereas cosmopolitanism and internationalism are negatively associated with antipathy toward foreign countries. In addition, Wang, $\mathrm{He}$, and Li (2013) reported that materialism and sensitivity to social norms can moderate the effect of consumer animosity on willingness to buy foreign products. Han (2017) also found that 
the cultural orientations of individualism and collectivism can precede consumer animosity and moderate the effects of consumer animosity on purchase intentions.

An examination of the effect of demographic characteristics on consumer animosity yielded mixed findings. As for gender, the majority of the studies (e.g., Fernández-Ferrín et al. 2015; Richardson 2012) reported that men show higher levels of animosity toward a hostile country than do women, while a few other studies (e.g., Bahaee and Pisani 2009) indicated the opposite. With regard to age, younger consumers felt stronger animosity toward the 'enemy nation' in Iran (Bahaee and Pisani 2009) and Indonesia (Sutikno and Cheng 2011), but the opposite was true in the case of the US (Klein and Ettenson 1999; Richardson 2012). Also, education was found to have either a positive (Ganideh and Elahee 2012; Nakos and Hajidimitriou 2007) or negative (Bahaee and Pisani 2009) association with consumer animosity, while in some studies (e.g., Fernández-Ferrín et al. 2015; Klein and Ettenson 1999) no significant relationship was observed.

\section{Consequences of consumer animosity}

Various attitudinal and behavioral consequences of consumer animosity were addressed by the majority of the studies in the field. Following the study of Klein, Ettenson, and Morris (1998), the earliest stream of research tried to validate the negative impact of consumer animosity on purchasing intentions in different cultural contexts. For instance, Witkowski (2000) studied the hostility of American consumers toward China and found that animosity is negatively associated with their purchasing intentions. This negative association was later confirmed by the studies on Korean consumers' attitudes toward Chinese products (Shin 2001), U.S. consumers' attitudes toward Japanese products (Klein 2002), Croatian consumers' attitudes toward Western products 
(Kesic, Rajh, and Yzerbyt 2005), and Australian consumers' attitudes toward French products (Ettenson and Klein 2005).

Many recent investigations (e.g., Funk et al., 2010; Ganideh and Elahee 2018; Maher and Mady 2010) similarly found a negative link between consumer animosity and willingness to buy products from the disliked nation, while a few others suggested that consumer antipathy also influences product judgments (Huang, Phau, and Lin 2010; Ishii 2009), preference for domestic products/products from one's in-group (Heinberg 2017; Shimp, Dunn, and Klein 2004), willingness to pay a price premium for products from one's in-group (Shimp, Dunn, and Klein 2004), and country-of-origin image (Hoffmann, Mai, and Smirnova 2011). Notably, some studies (e.g., Klein, Ettenson, and Morris 1998; Klein 2002; Mostafa 2010) examined the effect of willingness to buy on product ownership and reported their strong association.

\section{UNDERLYING THEORIES}

Our study is theoretically anchored on Realistic Group Conflict Theory (RGCT) (Sherif 1966), Social Identity Theory (SIT) (Tajfel and Turner 1986), and Self-Categorization Theory (SCT) (Turner et al. 1987). The RGCT and the SIT theories are useful in illuminating the nature of consumer animosity in general (Huang, Phau, and Lin 2010; Fernández-Ferrín et al. 2015), while the SCT explains why universal factors, such as personality traits and cultural orientations, could be relevant for the formation of one's attitudes and behavior, including consumer antipathy. Unlike theories that use psychological factors to explain conflict, the RGCT focuses on the situational antecedents outside the self. It holds that groups often have conflicting goals and compete for scarce resources, assuming that one group's success threatens other groups (Kervyn, Fiske, and Yzerbyt 2015). This often results in inter-group hostility, which is accompanied by 
feelings of prejudice and discrimination toward out-groups. These negative sentiments essentially stem from the belief that certain resources of the own group are threatened by other groups (Meuleman, Davidov, and Billiet 2009). Anti-out-group attitudes can thus be regarded as a response to the subjectively perceived threats to the interests of the in-group (Schlueter and Scheepers 2010). Notably, past studies (e.g., Schlueter and Scheepers 2010; Ullrich et al. 2006) have indicated a robust link between perceived group threat and discriminatory attitudes toward the out-group. The level of perceived group threat is largely determined by a context of actual conditions in which a conflict takes place (Meuleman, Davidov, and Billiet 2009). For instance, a more recent intragroup conflict enhances the feeling of membership and ethnic identification among the in-group's members and therefore increases perceptions of threat (Shoham et al. 2006). The latter leads to higher levels of anti-out-group sentiments, which serve to protect the in-group's interests in a particular conflict.

The insights of the RGCT were elaborated on by the SIT, which could further explain animosity beliefs. While the RGCT implies that conflicting goals are sufficient to cause confrontation between two groups, the SIT suggests that it is just the awareness of belonging to a particular group that creates prejudice against other groups (Tajfel and Turner 2004). According to the SIT, individuals tend to classify themselves and others into 'in-groups' and 'out-groups'. People constantly make comparisons between the in-groups and out-groups in order to achieve and maintain positive distinctiveness. They favor the in-group and discriminate against the outgroup, which allows them to boost their self-esteem (Tajfel and Turner 2004). This helps to generate a sense of identity, but also leads to conflicts between the in-group and the out-groups (Fong, Lee, and Du 2014; Shoham and Gavish 2016). In an animosity context, the home country is typically considered the in-group, whereas foreign countries are the out-group. The perceived 
differences between the in-group and out-groups might influence an individual's beliefs and behaviors in all spheres, including consumption patterns (Duckitt and Parra 2004). In the case of a past or ongoing conflict between countries, nationals of one country may adopt a negative attitude to a hostile country and its products because of heightened consciousness of their distinct identity (Huang, Phau, and Lin et al. 2010). This might result in an unwillingness to buy products from the hostile country.

Further, the combined use of personality traits and cultural orientations to explain consumer animosity can be theoretically justified by the Self-categorization theory (SCT). According to this theory, there are two aspects of the self: personal identity (the personal/inner self) and social identity (the social/outer self) (Onorato and Turner 2004). While the former refers to 'me' versus 'not me' categorizations and is rooted in the intrapsychic processes of an individual, the latter focuses on the 'us' versus 'them' categorizations and is rooted in sociocultural interactions between people (Rattansi and Phoenix 2005). Based on this theory, in our study we use personality traits as the inner self and cultural orientations as a proxy for the outer self, because they largely reflect an individual's perception of him- or herself within a particular group. Although this theory distinguishes between the personal identity and social identity of an individual, some studies (e.g., Markus and Kitayama 1991; Swann and Bosson 2008) underscore the interdependent nature of intrapsychic and sociocultural processes in the formation of an individual's identity. In fact, Vignoles (2018) argues that a person's identity is a broad and multifaceted concept, and any attempt to consider its levels in isolation may limit our understanding of the self and its effects on emotions, attitudes, and behavior. Hence, both personality traits (i.e., intrapsychic processes) and cultural orientations (i.e., sociocultural processes) determine how individuals interpret the world, and their combined use can provide a 
more integrative understanding of consumer negative feelings and behavior, as in the case of consumer animosity.

\section{CONCEPTUAL MODEL AND HYPOTHESES}

Our conceptual model posits that an individual's personality traits influence consumer animosity, which, in turn, positively affects foreign product avoidance (see Figure 1). The link between consumer animosity and foreign product avoidance is also hypothesized to be moderated by the cultural orientations of an individual. Finally, four demographic factors, namely gender, age, income group, and educational level, are used as control variables on consumer animosity.

\section{...Insert Figure 1 about here...}

\section{Main Hypothesized Paths}

The construct of personality rests on the assumption that individuals possess inherent characteristics which are remarkably stable throughout life (McCrae and Costa 1985). The Five Factor model/ Big Five is the most prominent taxonomy of personality, which categorizes a large number of traits into five dimensions, namely agreeableness, extraversion, conscientiousness, neuroticism, and openness to experience. The Five Factor Model was developed by exploring correlations among personality trait descriptors and has been consistently used to explain individual differences in a variety of empirical settings (McCrae and Costa 1985).

Agreeableness refers to an individual's level of empathy, warmth, and sympathy toward others (McCrae and John 1992). Agreeable individuals are generally friendly, compassionate, courteous, and soft-hearted (McCrae and Costa 1985). They also have a more optimistic view of human nature and are willing to compromise their interests with those of others (John and Srivastava 1999). In contrast, individuals with a low level of agreeableness tend to be less consid- 
erate, cooperative, and accommodating in their interpersonal interactions (Doucet et al. 2015). They also place self-interest above getting along with others and tend to be indifferent toward the welfare of the society. Previous research showed that agreeableness is associated with universalism and benevolence values, which incorporate anti-animosity dimensions, such as peacefulness, friendliness, and forgiveness (Olver and Mooradian 2003; Roccas et al. 2002). Indeed, agreeable people are less prejudiced and discriminatory against out-groups (Pratto et al. 1994) and very seldom respond destructively to different types of conflicts (Martin-Raugh, Kell, and Motowidlo 2016). In other words, individuals scoring high on the trait of agreeableness are likely to demonstrate less hostility toward the nation with which their home country is in a state of confrontation. Thus, we can posit:

$H_{1}$ : The higher the level of agreeableness of an individual, the lower his/her level of consumer animosity.

Extraversion refers to the extent to which a person is social, energetic, assertive, and outgoing (McCrae and Costa 1985). Extraverts enjoy participating in activities that involve social gatherings and are generally characterized by optimism, warmth, gregariousness, and excitement-seeking. On the contrary, individuals who are low in extraversion (i.e., introverts) are quiet, reserved, silent, and find social gatherings to be draining (McCrae and John 1992). The behavior of extraverts is largely driven by outer stimuli, while introverts need to escape such stimuli to gain functional equilibrium. Extroversion has also been consistently linked with the tendency to experience positive states (Srivastava, Angelo, and Vallereux 2008). In fact, the correlation between extraversion and positive affect was found so robust that some studies (e.g., Herringer 1999) proposed that positive emotionality is one of the defining features of extraversion, while other studies (e.g., DeNeve and Cooper 1998) pointed out that extraversion and positive affect 
are based on the same neurological structure. Since extraversion predisposes individuals to positive rather than negative emotionality, in the case of a conflict with another country, extraverts are likely to exhibit less animosity toward the offender. We may, therefore, hypothesize that:

$\mathrm{H}_{2}$ : The higher the level of extraversion of an individual, the lower his/her level of consumer animosity.

Conscientiousness is described as the tendency of an individual to be organized, responsible, and dependable, as well as to show self-discipline, adhere to rules and norms, and take obligations to others seriously (McCrae and Costa 1985). Conscientiousness is associated with educational accomplishment and determination to achieve high levels of success through purposeful planning (Goldberg 1993). Conscientious individuals are characterized by dutifulness, scrupulousness, and meticulousness, while people who score low on this trait demonstrate unreliability, frivolousness, lack of ambition and motivation, and failure to conform (McCrae and John 1992). Higher levels of conscientiousness have been associated with higher levels of positive affect (Steel, Schmidt, and Shultz 2008), which can be explained by the fact that conscientious people are characterized by effective emotion regulation and greater recovery from negative stimuli (Javaras et al. 2012). Hence, in the context of a confrontation between the home country and the foreign country, individuals scoring high on conscientiousness can activate this self-control mechanism to reduce negative affects arising from the conflicting situation. This is likely to make them less susceptible to feelings of animosity toward the hostility-evoking country, which leads us to the following hypothesis:

H3: The higher the level of conscientiousness of an individual, the lower his/her level of consumer animosity. 
Neuroticism denotes the tendency of an individual to experience negative emotional affects, such as anxiety, annoyance, and irritability (McCrae and Costa 1985). It also refers to an individual's ability to cope with potential stressful situations, as well as with feelings of insecurity, instability, and nervousness (Herold et al. 2002). Neurotic people exhibit negativity that persists for unusually long time periods and are often more worried, depressed, and fearful in their lives (McCrae and John 1992). They are also less likely to be accommodating in personal relations with out-groups and have difficulties in managing stress and reducing anxiety (Caligiuri and Tarique 2012). On the contrary, non-neurotic people are often calm, psychologically stable, and tend to be free from persistent negative feelings (John and Srivastava 1999). Overall, a high degree of neuroticism is linked to many aversive emotional feelings, with anger, aggression, and revenge being particularly evident (Ode, Robinson, and Witkowski 2008). This could be attributed to the poor emotional control of neurotic individuals, which increases their tendency to be more reactive to negative events, such as conflict between the home country and the foreign country on economic, political, societal, or military grounds (Ode, Robinson, and Witkowski 2008). Based on the above, we can hypothesize that:

H4: The higher the level of neuroticism of an individual, the higher his/her level of consumer animosity.

Openness describes the breadth, depth, and variability of one's longing for new ideas (John and Srivastava 1999). It refers to the extent to which a person is broad-minded, intelligent, and imaginative (McCrae and Costa 1985). Although generally openness denotes the individual's tendency for cognitive exploration, it has two distinct major components: openness to experience (related to aesthetics and emotions) and intellect (related to intellectual dispositions) (Kaufman et al. 2015). Overall, highly open individuals tend to think and act in nonconforming 
ways and are characterized by intellectual curiosity, aesthetic appreciation, creativity, and unconventionality. They are also more receptive to new ideas, values, and actions. In contrast, individuals scoring low on openness are more down-to-earth, have a conservative outlook, and prefer the familiar to the novel (Goldberg 1993). Notably, individuals who score high on openness have more empathy for individuals from other cultures, which is likely to reduce their negative feelings toward a foreign country in a conflicting situation (Ganideh and Elahee 2018; Shoham et al. 2006). Based on the above, we can posit that:

H5: The higher the level of openness of an individual, the lower his/her level of consumer animosity.

Consumer animosity has been well-researched in relation to consumers' purchase behavior. Klein, Ettenson, and Morris (1998) were the first to report a direct effect of animosity on consumer unwillingness to buy goods from a 'hostile' country, and this has been empirically confirmed in many subsequent studies (e.g., Ettenson and Klein 2005; Funk et al., 2010; Maher and Mady 2010; Mostafa 2010; Shoham et al. 2006). The positive association between consumer animosity and foreign product avoidance can be explained by the principle of cognitive consistency (Festinger 1957), which suggests that individuals have an inner drive to hold all their attitudes and behavior in harmony. When individuals hold two or more contradictory cognitions, they feel a negative affective state - cognitive dissonance. This unpleasant feeling motivates individuals to reduce the magnitude of dissonance by changing any one of the components that are responsible for the discrepancy (Festinger 1957). Thus, consumers with feelings of animosity toward a foreign country usually strive to balance their hostile attitudes with their behavioral responses by avoiding products from the offending country (Shoham et al. 2006). This alignment of attitude with behavior allows consumers to reduce the level of psychological 
distress and achieve cognitive consistency, that is, harmony among beliefs, attitudes, and actions. Notably, the association between consumer animosity and product avoidance was found to be stronger when the conflict between the home and the source country was more recent (Shoham, Gavish, and Rose 2016). Hence:

H6: Consumer animosity has a positive effect on foreign product avoidance.

\section{Moderation Hypotheses}

Our study applies Hofstede's (1980, 2001) typology of culture, comprising power distance, uncertainty avoidance, individualism, and masculinity, to examine the moderating effect of cultural characteristics on the association between consumer animosity and foreign product avoidance. While these dimensions have been widely employed at the country level, it has been observed that individuals in the same country also differ in their cultural orientations, which is related to their differences in the assimilation of culture of the society to which they belong (Yoo and Donthu 2005). Since the unit of analysis in our study is the individual, we assess culture at the individual rather than the country level, thus more accurately capturing cultural variations among people within the same country. This individual-level approach to culture has been successfully applied in other consumer behavior studies, such as those focusing on environmental issues (Leonidou, Leonidou, and Kvasova 2010), ethnocentrism (Yoo and Donthu 2005), and e-service quality perception (Al-Nasser et al. 2013).

Power distance refers to the extent to which less powerful individuals "expect and accept that power is distributed unequally" (Hofstede 2001, p. 98). Although inequality exists within any culture, people vary in the degree to which they accept that disparity. Individuals characterized by large power distance are more likely to conform to a hierarchy where everyone 
has a defined place within the social order. They also show greater reliance on the centralized authority and greater tolerance for inequalities in power and wealth (Hofstede 2001). In general, individuals who score highly on this cultural dimension are likely to exhibit stronger fears of disagreeing with their superiors and less questioning of authority (Kim and Zhang 2014). Since individuals of large power distance accept greater gaps in the hierarchy and show more conformity with authority, they are expected to exhibit more loyalty to their nation (Yoo and Donthu 2005). In the context of confrontation with another country, one of the manifestations of such loyalty is demonstration of disapproval toward the offending nation. Moreover, individuals scoring high on power distance carefully follow social guidelines in their attitudes and actions, and since the public stance on the animosity-evoking nation is often critical, the urge of such individuals 'to do the right thing' is likely to strengthen the association between their hostility toward the offending nation and product avoidance. Thus, we can propose the following hypothesis:

H7: The positive effect of consumer animosity on foreign product avoidance is stronger in the case of individuals with higher levels of power distance.

Uncertainty avoidance reflects an individual's tolerance for uncertainty and ambiguity (Hofstede 2001). Individuals with high levels of uncertainty avoidance feel uncomfortable in unstructured and unfamiliar situations, have an inner need for predictability and are intolerant of different opinions and behaviors. They feel threatened by the unknown, want to control the environment, and are largely risk-averse (Hofstede 1997). On the contrary, individuals with low levels of uncertainty avoidance are more comfortable with novel and unusual conditions, do not need explicit rules and instructions, show greater tolerance for different views and are willing to accept risk (Hofstede 2001). High uncertainty avoidance is also associated with reliance on 
formalized policies and procedures, while low uncertainty avoidance is linked to reliance on informal norms. In the context of confrontation between the home country and the foreign country, individuals of high uncertainty avoidance are likely to feel more stress and anxiety, since conflicts (especially those of a military nature) usually pose a threat to their home country and are generally associated with instability and insecurity. This enhanced feeling of nervousness is expected to strengthen the link between their animosity beliefs toward the hostile nation and foreign product avoidance. For this reason, we can posit that:

\section{$H_{8}$ : The positive effect of consumer animosity on foreign product avoidance is stronger in the case of individuals with higher levels of uncertainty avoidance.}

Individualism refers to the extent to which people act as individuals rather than as members of a group (Hofstede 1997). Individualists are independent of their groups, accord priority to their own interests, and consider the achievement of their personal goals of primary importance. On the contrary, collectivists are interdependent within their groups, give priority to the interests of their group, and seek to support the goals of their group, even at the expense of their own needs (Triandis 2001). Also, individualists behave primarily on the basis of their own attitudes, while collectivists tend to comply with the norms of the referent groups (Han 2017). The choices of collectivistic consumers often reflect their loyalty to the home country (their ingroup) and disbelief toward foreign countries (the out-groups), while individualistic consumers make choices based on rational judgments rather than group membership (Yoo and Donthu 2005). In the case of an international dispute, the prevailing public opinion about the offender and its products is often negative, and since collectivistic consumers are more susceptible to normative influence, their animosity feelings are likely to have a stronger effect on foreign 
product avoidance (Han 2017; Park and Yoon 2017). In contrast, individualistic consumers are more autonomous in their purchase decisions. We can therefore hypothesize that:

H9: The positive effect of consumer animosity on foreign product avoidance is stronger in the case of individuals with lower levels of individualism.

Masculinity refers to the dominant gender role pattern in a society. Specifically, masculinity represents a preference for assertiveness, achievement, and heroism, while femininity stands for cooperation, caring for others, and the quality of life (Hofstede 2001). Individuals characterized by high masculinity tend to be ambitious and competitive, dominate in all settings, strive for material success, and respect whatever is big, strong, and fast. On the other hand, individuals who score highly on femininity are usually tender, modest, cooperative, and care about interpersonal relations. Moreover, individuals high on masculinity often rely on onesided arguments and rush to embrace an antagonistic stance, while individuals high on femininity are usually open to two-sided communications and carefully consider different opinions before forming positive or negative attitudes (Yoo and Donthu 2005). In addition, people high on masculinity prefer confrontation as a method of conflict processing, while people high on femininity prefer harmony-enhancing procedures to avoid further conflict escalation (Leung et al. 1990). All the above imply that, in the context of confrontation between two countries, individuals with a high score in masculinity are likely to adopt a more hostile attitude toward an offending nation and show greater avoidance of its products. Hence, we may posit that:

H10: The positive effect of consumer animosity on foreign product avoidance is stronger in the case of individuals with higher levels of masculinity.

\section{RESEARCH METHOD}


The study took place in Ukraine, which, as mentioned earlier, provides fertile ground for the study of the consumer animosity phenomenon due to its current hostilities with Russia. However, to identify whether Russia is indeed the country to which Ukrainians feel the greatest animosity, as well as to reveal the specific animosity dimensions with regard to this country, in-depth interviews with 42 randomly selected Ukrainians were conducted by phone (lasting on average ten minutes). Respondents were asked to indicate the least favorable foreign country and explain their choices. The analysis of their responses showed that indeed Russia is the country toward which feelings of animosity are the strongest, having been mentioned 23 times (more than any other country). The other animosity target countries were: Poland ( 8 mentions), Germany (4 mentions), the US (4 mentions), Turkey (1 mention), India (1 mention), and Lithuania (1 mention).

Based on respondents' negative comments about Russia, four dimensions of animosity were determined: military (war), economic, political, and social. For instance, within a warrelated dimension, respondents pointed out the loss of the Crimea peninsula, the role of Russia in the military conflict in the Eastern region of Ukraine, and the threat that Russia poses to Ukrainian national security. Economic animosity was founded in the perceived Russian influence over the Ukrainian economy, where Russia-Ukraine gas disputes were believed to play the most important role. The manifestations of political animosity included dissatisfaction with Russian foreign policy and its negative consequences for Ukraine, as well as anger with the Russian president and other Russian politicians. Finally, within a social-related dimension, respondents referred to the Russian mentality/way of living and the fact that Russia tends to demonstrate its superiority over Ukraine. 
With regard to construct measurement (see Appendix II), the 'Big Five' personality traits were operationalized using the mini-IPIP, a 20-item short form of the 50-item IPIT-FiveFactor Model, which was developed by Donellan et al. (2006). The scales for each of the four dimensions of consumer animosity contained three items. These were largely taken from the studies of Klein, Ettenson, and Morris (1998) and Nes, Yelkur, and Silkoset (2012) and augmented with input from our preliminary interviews with Ukrainian consumers. General animosity was operationalized as a second-order construct with four animosity dimensions (i.e., military, economic, political, and social) as first-order constructs. This reflective measurement pattern for animosity was proposed by Klein, Ettenson, and Morris (1998) and Klein (2002) and applied by Rose, Rose, and Shoham (2009) and Fernández-Ferrín et al. (2015). ${ }^{\mathbf{1}}$ The 4-item scale for foreign product avoidance was taken from Grégoire, Tripp, and Legoux (2009) and Harmeling, Magnusson, and Singh (2015). The constructs comprising the four cultural dimensions of an individual were adapted from Hofstede (1980) and each measured on a 4-item scale.

Our questionnaire included questions containing pre-coded items for each of the constructs used in the conceptual model, measured on a 5-point Likert scale ranging from strongly disagree (1) to strongly agree (5). To reduce the potential for respondent bias, the following actions were taken: (a) some of the items in the scales were reversed; (b) the sequence of the various sections of the questionnaire was rotated; and (c) the respondents were assured that their answers would be strictly anonymous and confidential. The questionnaire was developed in English and translated into Russian and Ukrainian, while a back-translation procedure ensured that there were no linguistic problems. Since the majority of the respondents could speak both Ukrainian and Russian languages, they could choose the language of the questionnaire which was the most convenient for them. The questionnaire was pre-tested with five Ukrainian con- 
sumers, and no particular problems were identified with regard to duration, comprehension, and workability. $^{2}$

Data for the full-scale survey were collected during summer 2016, using the mallintercept method. Respondents were randomly intercepted in large shopping malls located in different parts of Ukraine. These included retail outlets targeting consumers of different genders, age groups, income groups, and education categories, which allowed us to achieve a relatively representative sample of the Ukrainian population aged 18 and above. However, due to the ongoing armed conflict in the Donbass region of Ukraine (which is in the eastern part of the country and borders Russia), access to consumers in this area was limited. All questionnaires were completed on a self-administered basis, while fieldwork supervisors were ready at any time to assist respondents to fill in the questionnaire and provide clarifications. ${ }^{3}$

Altogether, 1,195 visitors were intercepted, of which 484 refused to take part in the study, mainly because of time constraints, reluctance to reveal their attitude toward Russia, and general unwillingness to participate in surveys. Another 76 visitors, although willing to participate in the study, did not fulfil the eligibility criteria required in terms of age, education, or nationality. Of the remainder (i.e., 635 respondents), 29 questionnaires were not fully completed and were discarded from the survey. This indicates an effective response rate of $50.7 \%$, which is acceptable in the case of consumer surveys. To test for nonresponse bias, we have compared and contrasted the demographic characteristics (namely, gender, age, education level, and income group) between respondents and those non-respondents who could provide this information, revealing no statistically significant differences.

The final sample of 606 consumers had the following structure: with regard to location, $27 \%$ of the respondents were from Western Ukraine, $40 \%$ from Central Ukraine, and 33\% from 
Southern-Eastern Ukraine. In terms of gender, 59\% were males and $41 \%$ females. Regarding age, $32 \%$ were under the age of 35 and $68 \%$ aged 35 years and above. Finally, $65 \%$ of the respondents held at least an undergraduate university degree, while the remainder (35\%) had completed primary or secondary education. The fact that the sample is skewed toward consumers with a university degree reflects the general situation in the country, which is characterized by very high levels of tertiary education (The World Bank 2014).

\section{ANALYSIS AND RESULTS}

The data collected were analyzed using the Structural Equation Modeling based on the EQS program. We divided the analysis into two major parts: measurement model validation and structural model estimation.

\section{Measurement model validation}

Table 1 provides the correlation matrix, while Table 2 presents the results of the measurement model. The convergent validity of the constructs was adequate, since the $t$-value for each measurement item was high and significant, all standard errors of the estimated coefficients were very low, and the average variance extracted for each construct was greater than .50 (Hair et al. 2016). Discriminant validity was also evident, because the confidence interval around the correlation estimate for each pair of constructs never included 1.00 (Anderson and Gerbing 1988), while the squared correlation for each pair of constructs never exceeded their average variance extracted (Fornell and Larcker 1981). Construct reliability was satisfactory, since all constructs had Cronbach's alphas greater than .70. Composite reliability was also adequate, with all coefficients being greater than .60 . 


\section{...insert Table 1 and Table 2 about here...}

To ensure the non-existence of common method bias, we used three different tests. First, we employed the Harman's single-factor test (Podsakoff and Organ 1986), using exploratory factor analysis (EFA), where four factors emerged from the un-rotated solution with eigen values greater than 1.0 , accounting for $58 \%$ of the total variance. In addition, no general factor was evident, with the first factor accounting for less than $30 \%$ of the variance. Second, we applied a CFA approach to the Harman method, which is more sophisticated and rigorous than the EFA test (Podsakoff et al. 2003). Specifically, we estimated a confirmatory factor model, in which we constrained the four factors and 16 construct items used in our measurement model to load on a single factor. The fit statistics of this model indicated a very poor model fit (i.e., $\chi^{2}(104)=$ 989.42, $\left.p<.001 ; \chi^{2} / d f=9.51 ; \mathrm{NFI}=.83 ; \mathrm{NNFI}=.82 ; \mathrm{CFI}=.84 ; \mathrm{GFI}=.72, \mathrm{RMSEA}=.15\right)$. Finally, we used the partial correlation technique, where 'satisfaction with life' served as a marker variable (i.e., a theoretically unrelated construct), which neither exhibited a significant correlation with any other constructs used in the model, nor changed the significance of the correlation coefficients after implementing the partial correlation adjustments (Lindell and Whitney 2001).

\section{Structural model estimation}

The hypothesized links between the constructs were tested by estimating the structural model, which showed a good fit as demonstrated by the ratio of chi-square to the degrees of freedom $\left(\chi^{2} /\right.$ d.f. $\left.=2.3\right)$ and the results of alternative fit indexes $(\mathrm{NFI}=.94 ; \mathrm{NNFI}=.96 ; \mathrm{CFI}=.97$; RMSEA $=.05,90 \%$ C.I. $=(.04, .05))\left(\right.$ see Table 3). With regard to $\mathrm{H}_{1}$, the association between agreeableness and consumer animosity, although negative, was not statistically significant ( $\beta=$ $.03, t=-.53, p=.58)$. Extraversion was inversely and significantly related to consumer animosity, 
which is consistent with $\mathrm{H}_{2}(\beta=-.15, t=-3.14, p=.00)$. In support of $\mathrm{H}_{3}$, the effect of conscientiousness on consumer animosity was significant and with the right negative sign $(\beta=-.13, t=-$ 2.63, $p=.01)$, while neuroticism was positively associated with consumer antipathy $(\beta=.23, t=$ 4.81, $p=.00)$, thus confirming $\mathrm{H}_{4}$. Contrary to our expectations $\left(\mathrm{H}_{5}\right)$, openness was positively related to animosity $(\beta=.28, t=5.20, p=.00)$. Finally, in accord with $\mathrm{H}_{6}$, consumer animosity had a significant positive effect on foreign product avoidance $(\beta=.35, t=8.46, p=.00)$.

\section{...insert Table 3 about here...}

The moderation analysis was based on the interaction approach, which examines the effect of the cross-product between each moderating variable and the hypothesized association (Ping 1995). With regard to power distance, we found that it strengthens the positive effect of consumer animosity on foreign product avoidance $(\beta=.12, t=2.78, p=.01)$, thus confirming $\mathrm{H}_{7}$. Uncertainty avoidance also had a strong moderating effect on the relationship between consumer animosity and unwillingness to buy foreign products $(\beta=.14, t=3.35, p=.00)$, which is in accord with $\mathrm{H}_{8}$. Further, in support of $\mathrm{H}_{9}$, individualism weakened the impact of consumer animosity on foreign product avoidance $(\beta=-.18, t=-4.46, p=.00)$, while masculinity strengthened their association $(\beta=14, t=3.30, p=.00)$, which is in line with $\mathrm{H}_{10}$.

Finally, we have controlled for the effect of several demographic variables on consumer animosity. Our study demonstrated that gender is an important determinant of consumer hostility, with the intensity of animosity being higher in the case of male than female respondents $(\beta=$ $.40, t=-4.45, p=.00)$. Statistically significant results were also observed with regard to the role of education, with more educated individuals showing more negative sentiments to the hostilityevoking nation $(\beta=.16, t=3.95, p=.00)$. Surprisingly, both age $(\beta=.18, t=.61, p=.54)$ and income $(\beta=.07, t=.42, p=.68)$ had no significant effect on consumer animosity. 


\section{DISCUSSION AND IMPLICATIONS}

Although previous studies investigated the relationship between consumer animosity and many different factors, the role of personality traits in forming hostility feelings has never been tested. Moreover, while prior research found that the association between consumer animosity and purchase intentions is moderated by individualism/collectivism (Han 2017), the moderating role of other cultural orientations has not been investigated. We have addressed these gaps by examining the direct effect of personality traits on consumer animosity and the moderating effect of the main cultural orientations on the association between negative consumer sentiments toward a foreign country and product avoidance.

Our study has clearly indicated that certain personality traits influence consumer animosity which, in turn, affects product avoidance. In particular, extraversion was negatively related to consumer animosity, which can be explained by the fact that extraverts are characterized by warmth, positivism, and high levels of subjective well-being, which can partially offset their negative feelings toward the offending nation. The association between conscientiousness and consumer animosity was also negative, and one possible reason for this is that effective emotional control of conscientious individuals can reduce their negative affects toward a hostile country. Neuroticism had a significant positive impact on animosity, which can be attributed to the poor emotional control of neurotic people and their overreaction to negative events. Surprisingly, openness was negatively related to consumer animosity which could be ascribed to the fact that openness is linked, inter alia, to an individual's intellect, wider interests, and a tendency to experience more intense emotions, which might lead to higher levels of awareness of international conflicts and greater sensitivity to the negative actions of an animosity-provoking country. Fi- 
nally, the non-significant effect of agreeableness on consumer animosity can be partly attributed to the self-reported measures used in our study, which might have biased the results related to the socially desirable facets of agreeableness.

We also provided evidence that the strength of the association between consumer animosity and product avoidance is influenced by individual cultural orientations. Specifically, this link was stronger among individuals with higher levels of power distance, which could be explained by the fact that they are more loyal to their country and its government and thus more critical and punitive toward hostile actions of the offending nation. Similar results were found in the case of high-uncertainty avoidance individuals, which could be related to higher levels of discomfort, anxiety, and panic that these individuals feel in unexpected and unpleasant situations, such as hostilities between countries. The relationship between consumer animosity and product avoidance appeared to be weaker among consumers with higher levels of individualism, and one possible explanation for this is that individualistic consumers are autonomous in decision-making and therefore less likely to join their referent groups in displaying negative consumer attitudes and behavior. Finally, the greater impact of consumer animosity on foreign product avoidance, observed in the case of consumers scoring high on masculinity, could be explained by the fact that these individuals are more prone to open confrontation when experiencing negative feelings.

Finally, in line with previous studies (e.g., Fernández-Ferrín et al. 2015; Richardson 2012), our research has demonstrated that male consumers tend to show higher levels of animosity than their female counterparts, probably because during an ongoing conflict men are usually more directly involved in military actions and thus more vulnerable to the consequences of the conflict. Also, in accord with the studies of Ganideh and Elahee (2012) and Nakos and Hajidimitriou (2007), we indicated that educated individuals tend to show more antipathy toward the 
hostile country. One possible explanation for this is that more educated individuals closely follow political news and could therefore be more critical of the actions of the animosity-provoking nation. Finally, the non-significant findings of our study with regard to the role of age and income contradict those of other scholars (e.g., Bahaee and Pisani 2009; Sutikno and Cheng 2011; Rice and Wongtada 2007) who reported that younger and more affluent consumers are more likely to have a stronger feeling of animosity toward the offender.

\section{Theoretical Implications}

The findings of our study offer several theoretical implications. First, we extend previous work on the antecedents of consumer animosity by proving empirically that personality can be a crucial predictor of consumer cognitions. Our research examines broader, higher-order characteristics and thus moves beyond previously examined factors that often had a cursory role in explaining the consumer animosity phenomenon. Personality traits are deeply rooted in intrapsychic processes of individuals and determine relatively consistent patterns of their emotions, attitudes, and actions. They represent an individual's basic ways of experiencing and acting, and their structure is deemed to be universal across countries (McCrae and Costa 1987). Thus, personality characteristics largely reflect the inner self and allow to draw more reliable generalizations about cognitions of individuals with similar traits, including consumer attitudes

and behavior. As such, personality traits are fundamental constructs that synthesize multiple aspects of human nature and can therefore provide a more accurate perspective on consumers' antipathy toward specific countries.

Additionally, although Hofstede's (1980) typology of culture implies that individuals in one country form a uniform cultural group, this research suggests that individual consumers 
within one country are also culturally distinct, which results in differences in their buying behavior. This is consistent with the earlier conceptualizations of Yoo and Donthu (2005), who emphasized that cultural orientations of individual consumers can provide a more logical base for segmenting foreign markets than culture at the macro-country level. Cultural orientations reflect the outer self and are rooted in the sociocultural processes of individuals, and, together with personal traits, form one's identity (Markus and Kitayama 1998; Vignoles 2018). Indeed, personality cannot be easily separated from the cultural context in which it develops, and thus cultural orientations are also fundamental determinants of an individual's psychological profile. Hence, both personality and culture should be used as predictors and/or moderators in consumer animosity research and other international consumer studies.

Lastly, our research verified that consumer animosity is a complex phenomenon that is context-specific and can include multiple facets. This suggests that it is critical for the animosity scale to be adjusted through exploratory qualitative and/or quantitative research within the context of the specific investigation. This is in line with the earlier observations of Riefler and Diamantopoulos (2007), Nes, Yelkur, and Silkoset (2012), and Perviz et al. (2014), who argued that the usage of predetermined animosity measures limits our understanding of the nature of animosity (as well as its relationships with other constructs). Interestingly, the pioneering study of Klein, Ettenson, and Morris (1998, p. 92) also stressed this issue by developing "measures of the pan-cultural concept of animosity for specific use in China”.

\section{Managerial Implications}

From a managerial standpoint, our findings suggest that international companies operating in hostile markets should take foreign consumers' negative sentiments into consideration, since 
animosity is an important factor determining their buying behavior. If consumers in the target foreign market hold a high level of animosity, firms may want to minimize undesirable effects by taking a number of measures: (a) de-emphasizing the origin of their products, while at the same time stressing those attributes (e.g., distinctive features and functions) which are not related to the hostility-evoking country; (b) considering rebranding or localization of the brand name, as in the case of the Russian telecommunications company MobileTeleSystems (MTS) (the second largest mobile operator in Ukraine), which has been rebranded into 'Vodafone Ukraine'; and (c) masking country-of-origin information by establishing alliances with local companies or relocating to a neutral third country.

Managers should also take into consideration the target audience's personality traits when devising strategies for the foreign markets that harbor animosity toward their country. The results of our study revealed that consumers characterized by high extraversion, high conscientiousness, low neuroticism, and low openness exhibit less animosity toward a hostile country, and should therefore be the primary target groups in these countries. This could be achieved through the design of proper communication strategies in unfriendly markets. For example, with regard to message content, the negative effect of extraversion and conscientiousness on animosity should encourage companies to stress extraversion-related facets (e.g., excitement-seeking) and conscientiousness-related facets (e.g., high achievement). Similarly, the positive effect of neuroticism and openness on animosity calls for emphasizing non-neuroticism facets (e.g., tranquility) and non-openness facets (e.g., tradition). Notably, although large scale quantitative surveys could provide an accurate picture of personality profiles in hostile countries, both traditional (e.g., focus group discussions) and modern (e.g., social media content analysis) qualitative methods could also be helpful in identifying consumers' core personality traits. 
Moreover, our results suggest that companies facing animosity in a specific foreign market should take into account the cultural orientations of individual consumers when crafting international marketing strategies. Since animosity feelings of consumers that score high on power distance, uncertainty avoidance, collectivism, and masculinity are more likely to result in foreign product avoidance, firms should primarily target individuals with the opposite cultural orientations. For instance, focus on rationality, equality, and autonomy could be persuasive for individuals with low power distance, while the importance of interpersonal relations, quality of life, and tenderness would appeal to consumers with a high score in femininity. Novelty, risk, and adventure are also likely to attract consumers with low uncertainty avoidance, while an emphasis on 'I' vs. 'we' would be a credible argument for individualistic consumers.

Finally, managers of international firms should recognize that demographic characteristics might significantly impact consumer animosity and thus could serve as segmentation variables in hostile markets. For example, in the context of our study, the fact that males and more educated Ukrainians were found to show higher levels of animosity toward Russia implies that Russian firms should be wary of targeting these particular segments. However, these firms would have better chances to penetrate the huge and rapidly developing Ukrainian market by focusing mainly on women and less educated consumers. Overall, given the inconsistency of findings across various consumer animosity studies, it seems that the effects of consumer demographics should be seen within the specific national context in which the animosity issue is examined.

\section{FUTURE RESEARCH}


Future research could take several directions. First, our findings necessitate the replication of this study in other countries so as to verify whether the influence of personality traits and cultural orientations on consumer animosity is consistent across nations. In particular, there is a need to examine the role of these factors in shaping antipathy across countries with different types of animosity (e.g., stable vs. situational), different dimensions of animosity (e.g., war, economic, political, social, religious), and different intensity of animosity (e.g., strong vs. weak). Conducting multi-country studies would yield even more reliable results, which is necessary for extending the generalizability of our findings.

Second, it is important to monitor animosity longitudinally, since its intensity tends to change over time and shows inconsistent trends. For example, Klein, Ettenson, and Morris (1998) reported that the animosity of Chinese consumers toward Japan negatively affected their willingness to buy Japanese products 60 years after the Nanjing massacre and other tragic events of the Japan-China War (1937-1945), while Russian consumers have recently been found to be very willing to buy German goods, despite the unprecedented number of deaths suffered by the Soviet Union during the Second World War. The evolvement of animosity is difficult to predict, and thus hostility feelings should be monitored over time.

Third, future research could examine other possible antecedents of consumer animosity, such as ethical ideologies (e.g., idealism vs. relativism), social attributes (e.g., conservatism vs. liberalism), and personal values (e.g., self-direction vs. universalism). New research might also consider the role of geographical, economic, and cultural distance in shaping animosity beliefs and buying behavior. Animosity feelings could be moderated by an individual's political activity, foreign country travel, and multilingualism. Another possible antecedent of consumer negative sentiments is exposure to the mass media, and more importantly, the social media. 
Fourth, personality traits are associated with effective (e.g., conscientiousness) or ineffective (e.g., neuroticism) emotion regulation (Javaras et al. 2012; Ode, Robinson, and Witkowski 2008), and it would be interesting to explore this transformation mechanism in relation to animosity in more depth. For example, future research could consider appropriate management strategies for emotion regulation in hostile foreign markets. This might help to activate consumer self-control mechanisms to reduce negative affects arising from confrontation between the home country and the animosity-evoking country.

Fifth, future research could address negative consumer sentiments and behavior among various subgroups within a country (based, for example, on generation, religion, race, etc.). Although some studies (e.g., Hinck 2005; Rose, Rose, and Shoham 2009; Shimp, Dunn, and Klein 2004) have already explored causes and consequences of animosity among subcultures, this stream of research remains scarce and fragmented. Meanwhile, negative consumer attitudes of different types of subgroups could provide a more nuanced understanding of animosity.

Finally, it would be worthwhile to examine whether the effect of consumer animosity on product avoidance varies by product category, such as high-involvement products vs. lowinvolvement products, highly personal products vs. impersonal products, and conspicuous products vs. inconspicuous products. It is expected that high-involvement, personal, and conspicuous products would be associated with higher levels of consumer animosity and unwillingness to buy. Examining the effects of product category would assist researchers in gaining deeper insights into the consequences of consumer anger. 


\section{NOTES}

1. We used a reflective measurement pattern aiming to measure all four dimensions of consumer animosity and find an average score for general animosity, rather than explain how each of these dimensions influences general animosity, which, in this case, would be a formative measurement pattern. In studies with a formative measurement pattern, general animosity is usually operationalized as 'I dislike country $\mathrm{X}$ ' item (as opposed to our study, where general animosity is simply the average score of all dimensions of animosity). Also, the items that we used as observables 'reflect' consumer animosity (e.g., 'I dislike (the fact) that the Crimea peninsula has been illegally absorbed into the Russian Federation' or 'I dislike (the fact) that Russian national policy usually affects Ukraine in a negative way'), rather than 'form' consumer animosity, where the items would have a different formulation (e.g., 'The Crimea peninsula has been illegally absorbed into the Russian Federation' or 'Russian national policy usually affects Ukraine in a negative way').

2. 'Consistency effects' between personality trait measures and animosity measures were avoided because: (a) the way personality and animosity were measured is so different that it does not provide any hints to respondents to give consistent answers to the two constructs; and (b) the various sections in the questionnaire were systematically rotated during the fieldwork process, so that the respondents were not able to understand any associations between the two constructs.

3. To examine whether our results were sensitive to the residential area of consumers, we compared the degree of animosity reported by participants in the survey (those from Western, Central, and Southern-Eastern regions of Ukraine) on each of its four dimensions (i.e., military, economic, political, and social) using ANOVA test. The results revealed that people residing in the Southern-Eastern region had significantly lower levels of animosity compared to their counterparts living in the Western and Central regions, probably due to the closer historical links between this region and Russia. 


\section{REFERENCES}

Alden, Dana L., James B. Kelley, Petra Riefler, Julie A. Lee, Geoffrey N. Soutar (2013), “The Effect of Global Company Animosity on Global Brand Attitudes in Emerging and Developed Markets: Does Perceived Value Matter?”, Journal of International Marketing, 23 (2), 17-38.

Al-Nasser, Mohammad, Rushami ZienYusoff, Rabiul Islam, and Abdullah Al-Nasser (2013), "Cultural Differences Identification and Its Effect on E-Service Quality Perception", American Journal of Economics and Business Administration, 5 (2), 74-83.

Anderson, James C., and David W. Gerbing (1988), "Structural Equation Modeling in Practice: A Review and Recommended Two-Step Approach," Psychological Bulletin, 103 (3), 411-423.

Ang, Swee Hoon, Kwon Jung, Ah Keng Kau, Leong Siew Meng, Chanthika Pornpitakpan, and Soo Jiuan Tan (2004), "Animosity towards Economic Giants: What the Little Guys Think," Journal of Consumer Marketing, 21 (3), 190-207.

Bahaee, Mahmood, and Michael Pisani (2009), "Iranian Consumer Animosity and U.S. Products: A Witch's Brew or Elixir?," International Business Review, 18 (2), 199-210.

Bosnjak, Michael, Denis Bratko, Mirta Galesic, and Tracy Tuten (2007), "Consumer Personality and Individual Differences: Revitalizing a Temporarily Abandoned Field," Journal of Business Research, 60 (6), 587-589.

Caligiuri, Paula, and Ibraiz Tarique (2012), "Dynamic Cross-Cultural Competencies and Global Leadership Effectiveness, Journal of World Business," 47 (4), 612-622.

Cheah, Isaac, Ian Phau, Garick Kea, and Yu An Huang (2016), "Modelling Effects of Consumer Animosity: Consumers' Willingness to Buy Foreign and Hybrid Products," Journal of Retailing and Consumer Services, 30, 184-192.

DeNeve, Kristina M., and Harris Cooper (1998), “The Happy Personality: A Meta-Analysis of 137 Personality Traits and Subjective Well-Being," Psychological Bulletin, 124 (2), 197-229.

Donnellan, M. Brent, Frederick L. Oswald, Brendan M. Baird, and Richard E. Lucas (2006), "The MiniIPIP Scales: Tiny-yet-Effective Measures of the Big Five Factors of Personality," Psychological Assessment, 18 (2), 192-203.

Doucet, Lorna, Bo Shao, Lu Wang, and Greg Oldham (2015), "I Know How You Feel, but It Does Not Always Help: Integrating Emotion Recognition, Agreeableness, and Cognitive Ability in a Compensatory Model of Service Performance," Journal of Service Management, 27 (3), 1-42.

Duckitt, John, and Cristina Parra (2004), "Dimensions of Group Identification and Out-Group Attitudes in Four Ethnic Groups in New Zealand," Basic and Applied Social Psychology, 26 (4), 237-247.

Ettenson, Richard, and Jill Gabrielle Klein (2005), "The Fallout from French Nuclear Testing in the South Pacific: A Longitudinal Study of Consumer Boycott," International Marketing Review, 22 (2), 199-224.

Fernández-Ferrín, Pilar, Belen Bande-Vilela, Jill Gabrielle Klein, and Maria Luisa del Río-Araújo (2015), "Consumer Ethnocentrism and Consumer Animosity: Antecedents and Consequences," International Journal of Emerging Markets, 10 (1), 73-88.

Festinger, Leon (1957), “A Theory of Cognitive Dissonance”, Stanford University Press.

Fong, Cher-Min, Chun-Ling Lee, and Yunzhou Du (2014), "Consumer Animosity, Country of Origin, and Foreign Entry-Mode Choice: A Cross-Country Investigation", Journal of International Marketing, 22 (1), 62-76.

Fornell, Claes, and David F. Larcker (1981), "Evaluating Structural Equation Models with Unobservable Variables and Measurement Error," Journal of Marketing Research, 18 (1), 39-40.

Funk, Charles, Jonathan Arthurs, Len Trevino, and Jeff Joireman (2010), "Consumer Animosity in the Global Value Chain: The Effect of International Production Shifts on a Willingness to Purchase Hybrid Products," Journal of International Business Studies, 41 (4), 639-651. 
Ganideh, Saeb and Mohammad Elahee (2012), "Arab Spring and Jordanian Consumers' Animosity toward Foreign Products: What Managers Need to Know," Journal of Comparative International Management, 15 (1), 86-97.

Ganideh, Saeb, and Mohammad Elahee (2018), "Dealing with 'Enemy-Brothers': Sunni-Arab Consumers' Animosity toward Iran and Turkey", Journal of Consumer Marketing.

Gineikiene, Justina, and Adamantios Diamantopoulos (2017), "I Hate Where It Comes from but I Still Buy It: Countervailing Influences of Animosity and Nostalgia," Journal of International Business Studies, 48 (8), 992-1008.

Goldberg, Lewis R. (1993), "The Structure of Phenotypic Personality Traits," American Psychologist, 48 (1), 26-34.

Griffith, David A., Goksel Yalcinkaya, and Gaia Rubera (2014), "Country-Level Performance of New Experience Products in a Global Rollout: The Moderating Effects of Economic Wealth and National Culture," Journal of International Marketing, 22 (4), 1-20.

Grégoire, Yany, Thomas M. Tripp, and Renaud Legoux (2009), "When Customer Love Turns into Lasting Hate: The Effects of Relationship Strength and Time on Customer Revenge and Avoidance," Journal of Marketing, 73 (6), 18-32.

Gürhan-Canli, Zeynep, GülenSarıal-Abi, and Ceren Hayran (2018), "Consumers and Brands across the Globe: Research Synthesis and New Directions”. Journal of International Marketing, 26, (1), 96117.

Hair, Joseph F. Jr., William C.Black, Barry J. Babin, and Rolph E. Anderson (2010), Multivariate Data Analysis (7th ed.), Upper Saddle River, NJ: Pearson Education.

Han, Min (2017), "Individualism, Collectivism, and Consumer Animosity in Emerging Asia: Evidence from Korea," Journal of Consumer Marketing, 34 (4), 359-370.

Harmeling, Colleen, Peter Magnusson, and Nitish Singh (2015), "Beyond Anger: A Deeper Look at Consumer Animosity," Journal of International Business Studies, 46 (6), 1-18.

Heinberg, Martin (2017), "Outbreaks of Animosity Against the West in China: Effects on Local Brand Consumption", International Marketing Review, 34 (4), 514-535.

Herold, David M., Walter Davis, Donald B. Fedor, and Charles K. Parsons (2002), "Dispositional Influences on Transfer of Learning in Multistage Training Programs," Personnel Psychology, 55 (4), 851-869.

Herringer, Lawrence (1999), "Facets of Extraversion Related to Life Satisfaction," Personality and Individual Differences, 24 (5), 731-733.

Hinck, Wolfgang (2005), "The Role of Domestic Animosity in Consumer Choice: Empirical Evidence from Germany," Journal of Euromarketing, 14 (1-2), 87-104.

Hirsh, Jakob B., and Dan Dolderman, D (2007), "Personality Predictors of Consumerism and Environmentalism: A Preliminary Study", Personality and Individual Differences, 43, 1583-1593.

Hoffmann, Stefan, Rober Mai, and Maria Smirnova (2011), "Development and Validation of a CrossNationally Stable Scale of Consumer Animosity," Journal of Marketing Theory and Practice, 19 (2), 235-252.

Hofstede, Geert (1980), Culture's Consequences: International Differences in Work-Related Values, Beverly Hills, CA: Sage.

Hofstede, Geert (1997), Cultures and Organizations: Software of the Mind, London: McGraw-Hill.

Hofstede, Geert (2001), Culture's Consequences: Comparing Values, Behaviors, Institutions and Organizations across Nations, Thousand Oaks, CA: Sage (co-published in the PRC as Vol. 10 in the Shanghai Foreign Language Education Press SFLEP Intercultural Communication Reference Series, 2008).

Huang, Yu-An, Ian Phau, and Chad Lin (2010), "Consumer Animosity, Economic Hardship, and Normative Influence. How do They Affect Consumers' Purchase Intention?,” European Journal of 
Marketing, 44 (7/8), 909-937.

Ishii, Kenichi (2009), "Nationalistic Sentiments of Chinese Consumers: The Effects and Determinants of Animosity and Consumer Ethnocentrism," Journal of International Consumer Marketing, 21 (4), 299-308.

Jakubanecs, Alexander, Magne Supphellen, and Helge Thorbjornsen (2005), "Slavic Brothers or Rivals?, ” Journal of East-West Business, 10 (4), 55-78.

Javaras, Kristin N., Stacey M. Schaefer, Carien M. van Reekum, Regina C. Lapate, Lawrence L. Greischar, David R. Bachhuber, Gayle Dienberg Love, Carol D. Ryff, and Richard J. Davidson, (2012), "Conscientiousness Predicts Greater Recovery from Negative Emotion," Emotion, 2 (5), $875-881$.

John, Oliver P., and Sanjay Srivastava (1999), "The Big Five Trait Taxonomy: History, Measurement, and Theoretical Perspectives," In L. A. Pervin \& O. P. John (Eds.), Handbook of Personality: Theory and Research, 102-138.

Jung, Kwon, Swee Hoon Ang, Siew Meng Leong, Soo Jiuan Tan, Chanthika Pornpitakpan, Ah Keng Kau (2002), "A Typology of Animosity and Its Cross-National Validation," Journal of CrossCultural Psychology, 33 (6), 525-539.

Kaufman, Scott, Lena Quilty, Rachael Grazioplene, Jacob Hirsh, Jeremy Gray, Jordan Peterson, and Colin DeYoung (2015), "Openness to Experience and Intellect Differentially Predict Creative Achievement in the Arts and Sciences," Journal of Personality, 84 (2), 248-258.

Kervyn, Nicolas, Susan Fiske, and Vincent Yzerbyt (2015), "Forecasting the Primary Dimension of Social Perception: Symbolic and Realistic Threats Together Predict Warmth in the Stereotype Content Model," Social Psychology, 46 (1), 36-45.

Kesic, Tanja, Rajh P. Piri, and Goran Vlasic (2005), "The Role of Nationalism in Consumer Ethnocentrism and the Animosity in the Post-War Country," paper presented at the 34th European Marketing Conference, May 24-27, Milan.

Kim, Youngseon, and Yinlong Zhang (2014), “The Impact of Power-Distance Belief on Consumers' Preference for Status Brands," Journal of Global Marketing, 27 (1), 13-29.

Klein, Jill Gabrielle, Richard Ettenson, and Marlene Morris (1998), "The Animosity Model of Foreign Product Purchase: An Empirical Test in the People's Republic of China," Journal of Marketing, 62 (1), 89-100.

Klein, Jill Gabrielle, and Richard Ettenson (1999), "Consumer Animosity and Consumer Ethnocentrism," Journal of International Consumer Marketing, 11 (4), 5-24.

Klein, Jill Gabrielle (2002), "Us Versus Them, or Us Versus Everyone? Delineating Consumer Aversion to Foreign Goods," Journal of International Business Studies, 33 (2), 345-363.

Leonidou Leonidas C., Constantinos N. Leonidou, and Olga Kvasova (2010), "Antecedents and Outcomes of Consumer Environmentally Friendly Attitudes and Behavior", Journal of Marketing Management, 26 (13 \& 14), 1319 - 1344.

Leung, Kwok, Michael H. Bond, D. William Carment, Lila Krishnan, and Wim B. G. Liebrand (1990), "Effects of Cultural Femininity on Preference for Methods of Conflict Processing: A Cross-Cultural Study," Journal of Experimental Social Psychology, 26 (5), 373-388.

Lin, Hsin-Chen, and Manohar U. Kalwani (2018), "Culturally Contingent Electronic Word-of-Mouth Signaling and Screening: A Comparative Study of Product Reviews in the United States and Japan", Journal of International Marketing, 26 (2), 80-102.

Lindell, Michael K., and David J. Whitney (2001), "Accounting for Common Method Variance in Cross-Sectional Research Designs", Journal of Applied Psychology, 86(1), 114-121.

Ma, Jun, Sijun Wang, and Wei Hao (2012), "Does Cultural Similarity Matter? Extending the Animosity Model from a New Perspective," Journal of Consumer Marketing, 29 (5), 319-332.

Maher, Amro, and Sarah Mady (2010), "Animosity, Subjective Norms, and Anticipated Emotions During an International Crisis," International Marketing Review, 27 (6), 630-651. 
Markus, Hazel R., and Shinobu, Kitayama (1991), "Culture and the Self: Implications for Cognition, Emotion, and Motivation”, Psychological Review, 98 (2), 224-253

Martin-Raugh, Michelle, Harrison Kell, and Stephan Motowidlo (2016), "Prosocial Knowledge Mediates Effects of Agreeableness and Emotional Intelligence on Prosocial Behavior," Personality and Individual Differences, 90, 41-49.

McCrae, Robert R., and Paul T. Costa (1985), "Comparison of EPI and Psychoticism Scales with Measures of the 5-Factor Model of Personality," Personality and Individual Differences, 6, 587-597.

McCrae, Robert R., and Paul T. Costa (1987), "Validation of the Five-Factor Model of Personality across Instruments and Observers", Journal of Personality and Social Psychology, 52(1), 81-90.

McCrae, Robert R., and Oliver P. John (1992), "An introduction to the Five Factor Model and Its Applications," Journal of Personality, 60 (2), 175-216.

Meuleman, Bart, Davidov Eldad and Billiet Jaak (2009), "Changing Attitudes toward Immigration in Europe, 2002-2007: A Dynamic Group Conflict Theory Approach," Social Science Research, 38 (2), $352-365$.

Mooij, Marieke, and Geert Hofstede (2011), "Cross-Cultural Consumer Behavior: A Review of Research Findings," Journal of International Consumer Marketing, 23(3-4), 181-192.

Mostafa, Mohamed (2010), "A Structural Equation Analysis of the Animosity Model of Foreign Product Purchase in Egypt," Global Business Review, 11 (3), 347-363.

Nakos, George, and Yanis Hajidimitriou (2007), "The Impact of National Animosity on Consumer Purchases: The Modifying Factor of Personal Characteristics," Journal of International Consumer Marketing, 19 (3), 53-72.

Nes, Erik B, Rama Yelkur, and Ragnhild Silkoset (2012), "Exploring the Animosity Domain and the Role of Affect in a Cross-National Context," International Business Review, 21(5), 751-765.

Nijssen, Edwin, and Susan Douglas (2004), "Examining the Animosity Model in a Country with a High Level of Foreign Trade," International Journal of Research in Marketing, 21, 23-38.

Ode, Scott, Michael Robinson, and Benjamin Wilkowski (2008), "Can One's Temper be Cooled?: A Role for Agreeableness in Moderating Neuroticism's Influence on Anger and Aggression,” Journal of Research in Personality, 42 (2), 295-311.

Olver, James M., and Todd A. Mooradian (2003), "Personality Traits and Personal Values: A Conceptual and Empirical Integration," Personality and Individual Differences, 35 (1), 109-125.

Onorato, Rina S., and John C.Turner (2004) "Fluidity in the Self-Concept: The Shift from Personal to Social Identity", European Journal of Social Psychology, 34, 257-278.

Papadopoulos, Nicolas, Alia El Banna, and Steven A. Murphy (2017), "Old Country Passions: An International Examination of Country Image, Animosity, and Affinity Among Ethnic Consumers”, Journal of International Marketing, 25 (3), 61-82.

Park, Ji Eun, and Sung-Joon Yoon (2017), "Antecedents of Consumer Animosity and the Role of Product Involvement on Purchase Intentions," American Journal of Business, 32 (1), 42-57.

Perviz, Lejla, Tina Gec, Irena Vida, and Tanja Dmitrovic (2014), "The Origins and Consequences of Consumer Animosity in Slovenia: a Qualitative Study," Economic and business review, 16 (2), 133161.

Pick, Dorren, and Martin Eisend (2016), "Customer Responses to Switching Costs: A MetaAnalytic Investigation of the Moderating Influence of Culture," Journal of International Marketing, 24 (4), 39-60.

Ping, Robert, A. (1995), "Parsimonious Estimating Technique for Interaction and Quadratic Latent Variables", Journal of Marketing Research, 32 (3), 336-347.

Podsakoff, Philip M., and Dennis W. Organ (1986), "Self-Reports in Organizational Research: Problems and Prospects," Journal of Management, 12 (4), 531-544. 
Podsakoff, Philip M., Scott B. MacKenzie, Jeong-Yeon Lee, and Nathan P. Podsakoff (2003), "Common Method Biases in Behavioral Research: A Critical Review of the Literature and Recommended Remedies", Journal of Applied Psychology, 88(5), 879-903.

Pratto, Felicia, James Sidanius, Lisa M. Stallworth, and Bertram F. Malle (1994), "Social Dominance Orientation: A Personality Variable Predicting Social and Political Attitudes", Journal of Personality and Social Psychology, 67 (4), 741-763.

Rattansi, Ali, and Ann Phoenix (2005), "Rethinking Youth Identities: Modernist and Postmodernist Frameworks", Identity, 5 (2), 97-123.

Rice, Gillian, and Nittaya Wongtada (2007), "Conceptualizing Inter-Attitudinal Conflict in Consumer Response to Foreign Brands", Journal of International Consumer Marketing, 20 (1), 51-65

Richardson, Charles (2012), "Consumer Demographics as Antecedents in the Animosity Model of Foreign Product Purchase,” International Journal of Business and Social Science, 3 (4), 13-21.

Riefler, Petra, and Adamantios Diamantopoulos (2007), "Consumer Animosity: a Literature Review and a Reconsideration of Its Measurement", International Marketing Review, 24 (1), 87-119.

Roccas, Sonia, Lilach Sagiv, Shalom H. Schwartz, and Ariel Knafo (2002), "The Big Five Personality Factors and Personal Values,” Personality and Social Psychology Bulletin, 28 (6), 789-801.

Rose, Mei, Gregory M. Rose, and Aviv Shoham (2009), "The Impact of Consumer Animosity on Attitudes towards Foreign Goods: A Study of Jewish and Arab Israelis," Journal of Consumer Marketing, 26 (5), 330-339.

Schlueter, Elmar, and Peers Scheepers (2010), "The Relationship between Outgroup Size and AntiOutgroup Attitudes: a Theoretical Synthesis and Empirical Test of Group Threat and Intergroup Contact Theory," Social Science Research, 39 (2), 285-295.

Sherif, Muzafer (1966), "Group Conflict and Cooperation: Their Social Psychology", London: Routledge \& Kegan Paul.

Shimp, Terence A., and Subhash Sharma (1987), "Consumer Ethnocentrism: Construction and Validation of the CETSCALE," Journal of Marketing Research, 24 (3), 280-289.

Shimp, Terence A., Tracy H. Dunn, and Jill Gabrielle Klein (2004), "Remnants of the US Civil War and Modern Consumer Behaviour," Psychology and Marketing, 21 (2), 75-91.

Shin, Mincheol (2001), "The Animosity Model of Foreign Product Purchase Revisited: Does It Work in Korea?," Journal of Empirical Generalisations in Marketing Science, 6 (1), 1-14.

Shoham, Aviv, and Yossi Gavish (2016), "Antecedents and Buying Behavior Consequences of Consumer Racism, National Identification, Consumer Animosity, and Consumer Ethnocentrism", Journal of International Consumer Marketing, 28 (5), 296-308.

Shoham, Aviv, Moshe Davidow, Jill Gabrielle Klein, and AyallaRuvio (2006), "Animosity on the Home Front: The Intifada in Israel and Its Impact on Consumer Behaviour," Journal of International Marketing, 14 (3), 92-114.

Shoham, Aviv, Yossi Gavish, and Gregory M. Rose (2016), "Consequences of Consumer Animosity: A Meta-Analytic Integration," Journal of International Consumer Marketing, 28 (3), 185-200.

Srivastava, Sanjay, Kimberly M. Angelo and Shawn R. Vallereux (2008), "Extraversion and Positive Affect: A Day Reconstruction Study of Person-Environment Transactions," Journal of Research in Personality, 42 (6), 1613-1618.

Steel, Piers, Joseph Schmidt, and Jonas Shultz (2008), "Refining the Relationship between Personality and Subjective Well-Being," Psychological Bulletin, 134 (1), 138-161.

Sutikno, Bayu, and Julian Ming-Sung Cheng (2011), "Towards Consumer Ethnocentrism and Animosity in Indonesia," International Journal of Management and Business Research, 1 (1), 15-18.

Swann, William B. Jr., and Jennifer K. Bosson (2008), "Identity Negotiation: A Theory of Self and Social Interaction", in O. P. John, R. W. Robins, \& L. A. Pervin (Eds.), Handbook of personality: Theory and research (3rd ed., pp. 448-471). New York, NY: Guilford Press 
Tajfel, Henri, and John C. Turner (1986), "The Social Identity Theory of Intergroup Behavior," Psychology of Intergroup Relations, 5, 7-24.

Tajfel, Henri, and John C. Turner (2004), "The Social Identity Theory of Intergroup Behavior," in J. T. Jost\& J. Sidanius (Eds.), Key Readings in Social Psychology. Political psychology: Key Readings (pp. 276-293). New York, NY, US: Psychology Press.

Tang, Linghui (2017),"Mine Your Customers or Mine Your Business: The Moderating Role of Culture in Online Word-of-Mouth Reviews,"Journal of International Marketing, 25 (2), 88-110.

Thompson, Edmund R., and Gerard P. Prendergast (2015), "The Influence of Trait Affect and the FiveFactor Personality Model on Impulse Buying," Personality and Individual Differences, 76, 216-221.

Triandis, Harry C. (2001), "Individualism-Collectivism and Personality," Journal of Personality, 69 (6), 907-924.

Turner, J. C., M. A. Hogg, P. J. Oakes, S. D. Reicher, and M. S. Wetherell (1987), Rediscovering the Social Group: A Self-Categorization Theory. Oxford, England: Blackwell.

Ullrich, Johannes, Oliver Christ, and Elmar Schlueter (2006), "Merging on Mayday: Subgroup and Superordinate Identification as Joint Moderators of Threat Effects in the Context of European Union's expansion," European Journal of Social Psychology, 36(6), 857-876.

Vignoles, Vivian (2018), "Identity: Personal AND Social” In: Deaux, Kay and Snyder, Mark (Eds.), Oxford Handbook of Personality and Social Psychology,2nd ed.,. Oxford.

Wang, Weiyue, Hongwei He, and Yan Li (2013), "Animosity and Willingness to Buy Foreign Products: Moderating Factors in Decision-Making of Chinese Consumers," Asia Pacific Business Review, 19 (1), 32-52.

Westjohn, Stanford A., Nitish Singh, and Peter Magnusson (2012), "Responsiveness to Global and Local Consumer Culture Positioning: A Personality and Collective Identity Perspective," Journal of International Marketing, 20 (1), 58-73.

Witkowski, Terrence H. (2000), "Effect of Animosity towards China on Willingness to Buy Chinese Products," in McClean, G., Kaynak, E. and Aliaga, O. (Eds), Managing in a Turbulent International Business Environment, The International Management Development Association, Hummelstown, PA, 470-777.

Yeniyurt, Sengun, and Janell Townsend (2003) "Does Culture Explain Acceptance of New Products in a Country?: An Empirical Investigation", International Marketing Review, 20 (4), 377-396.

Yoo, Boonghee and Naveen Donthu, (2005), "The Effect of Personal Cultural Orientation on Consumer Ethnocentrism: Evaluations and Behaviors of US Consumers toward Japanese Products," Journal of International Consumer Marketing, 18 (1-2), 7-44. 
APPENDIX I: Summary of Empirical Studies on Consumer Animosity

\begin{tabular}{llll}
\hline Study & Objectives & Method & Key findings \\
\hline Klein, & To conduct an initial test of the & A 'mall & Animosity has significant impact on buying \\
Ettenson, and & animosity model of foreign product & intercept' & decisions above and beyond the effect of consumer \\
Morris & purchase. & survey & ethnocentrism. Animosity affects negatively the \\
(1998) & & $\begin{array}{l}\text { Chinese } 244 \\
\text { purchase of products independently of judgments of } \\
\text { consumers. }\end{array}$ & $\begin{array}{l}\text { product quality. } \\
\end{array}$ \\
& &
\end{tabular}

\begin{tabular}{|c|c|c|c|}
\hline $\begin{array}{l}\text { Klein and } \\
\text { Ettenson } \\
\text { (1999) }\end{array}$ & $\begin{array}{l}\text { To determine the unique } \\
\text { antecedents of the consumer } \\
\text { animosity and consumer } \\
\text { ethnocentrism constructs. }\end{array}$ & $\begin{array}{l}\text { Logit } \\
\text { regression } \\
\text { using the } \\
\text { data from } \\
\text { the US } 1992 \\
\text { National } \\
\text { Election } \\
\text { Study. }\end{array}$ & $\begin{array}{l}\text { The profile of the ethnocentric consumer is } \\
\text { different from the consumer holding animosity } \\
\text { towards a specific country. }\end{array}$ \\
\hline $\begin{array}{l}\text { Shin } \\
(2001)\end{array}$ & $\begin{array}{l}\text { To assess the generalizability of } \\
\text { consumer animosity model. }\end{array}$ & $\begin{array}{l}\text { A survey } \\
\text { among } 228 \\
\text { Korean } \\
\text { students. }\end{array}$ & $\begin{array}{l}\text { Animosity is negatively associated with willingness } \\
\text { to buy, while country of origin is positively } \\
\text { associated with willingness to buy. }\end{array}$ \\
\hline
\end{tabular}

\begin{tabular}{llll}
\hline Klein & To identify differences between & A survey \\
consumer animosity and consumer & among 202 \\
ethnocentrism. & $\begin{array}{l}\text { American } \\
\text { consumers. }\end{array}$ & $\begin{array}{l}\text { Animosity toward a foreign nation is related to } \\
\text { choices between foreign goods, while consumer } \\
\text { ethocentrism is related to choices between } \\
\text { domestic and foreign goods. }\end{array}$
\end{tabular}

\begin{tabular}{llll}
\hline $\begin{array}{l}\text { Jung } \text { et al. } \\
(2002)\end{array}$ & $\begin{array}{l}\text { To develop and test a typology of } \\
\text { animosity. }\end{array}$ & $\begin{array}{l}\text { A survey } \\
\text { among } 400\end{array}$ & $\begin{array}{l}\text { Four types of animosity were established: } \\
\text { situational vs. stable and personal vs. national. }\end{array}$ \\
& Asian & \\
& consumers \\
& from five \\
& countries.
\end{tabular}

\begin{tabular}{llll}
\hline $\begin{array}{l}\text { Ang } \text { et al. } \\
\text { (2004) }\end{array}$ & $\begin{array}{l}\text { To examine consumer animosity, } \\
\text { ethnocentrism and attribution } \\
\text { towards USA and Japan. }\end{array}$ & $\begin{array}{l}\text { A survey } \\
\text { among 2000 } \\
\text { consumers } \\
\text { from five } \\
\text { Asian } \\
\text { countries. }\end{array}$ & $\begin{array}{l}\text { Animosity might be situational vs. stable and } \\
\text { personal vs. national. }\end{array}$ \\
& & $\begin{array}{l}\text { A survey } \\
\text { among 219 } \\
\text { Dutch } \\
\text { consumers. }\end{array}$ & $\begin{array}{l}\text { Consumer ethnocentrism and animosity have an } \\
\text { impact on the evaluation of foreign products, even } \\
\text { when no domestic brands are available. }\end{array}$ \\
\hline $\begin{array}{l}\text { Nissen and } \\
\text { (2004) }\end{array}$ & $\begin{array}{l}\text { To examine the effects of consumer } \\
\text { animosity and ethnocentrism in the } \\
\text { country with high foreign trade and } \\
\text { lack of domestic product } \\
\text { alternatives. }\end{array}$ & $\begin{array}{l}\text { A survey } \\
\text { among 337 } \\
\text { respondents. }\end{array}$ & $\begin{array}{l}\text { Regional animosity influences purchase choice and } \\
\text { willingness to pay a price premium for preferred } \\
\text { options from one's in-group region. }\end{array}$ \\
\hline $\begin{array}{l}\text { Shimp, Dunn, } \\
\text { and Klein } \\
\text { (2004) }\end{array}$ & $\begin{array}{l}\text { To investigate the effects of intra- } \\
\text { state (regional) animosity. }\end{array}$ & $\begin{array}{l}\text { A survey of } \\
135 \text { Jewish }\end{array}$ & $\begin{array}{l}\text { Dogmatism, nationalism, and internationalism } \\
\text { affect animosity, which in turn predicts willingness } \\
\text { to buy and actual changes in purchase behavior. }\end{array}$ \\
\hline $\begin{array}{l}\text { Shoham, Da- } \\
\text { vidow, } \\
\text { Klein, and }\end{array}$ & $\begin{array}{l}\text { To examine antecedents and } \\
\text { consequences of animosity. }\end{array}$ & & \\
\hline & & &
\end{tabular}




\begin{tabular}{|c|c|c|c|}
\hline $\begin{array}{l}\text { Ruvio } \\
(2006)\end{array}$ & & consumers. & \\
\hline $\begin{array}{l}\text { Riefler and } \\
\text { Diamantopoul } \\
\text { os } \\
(2007)\end{array}$ & $\begin{array}{l}\text { To conduct a review of the } \\
\text { consumer animosity research. }\end{array}$ & $\begin{array}{l}\text { A survey } \\
\text { among } 89 \\
\text { Austrian } \\
\text { consumers. }\end{array}$ & $\begin{array}{l}\text { Consumers differ in their animosity targets, and } \\
\text { there may be a number of (different) reasons } \\
\text { causing animosity such as economic, political, } \\
\text { religious or personal. }\end{array}$ \\
\hline $\begin{array}{l}\text { Bahaee and } \\
\text { Pisani } \\
\text { (2009) }\end{array}$ & $\begin{array}{l}\text { To test the animosity model in the } \\
\text { context of Iran. }\end{array}$ & $\begin{array}{l}\text { A survey } \\
\text { among } 900 \\
\text { Iranian } \\
\text { consumers. }\end{array}$ & $\begin{array}{l}\text { Certain demographic variables are associated with } \\
\text { consumer animosity. There is a strong and } \\
\text { significant inverse relationship between consumer } \\
\text { animosity and intention to buy. }\end{array}$ \\
\hline $\begin{array}{l}\text { Ishii } \\
(2009)\end{array}$ & $\begin{array}{l}\text { To examine the antecedents of } \\
\text { consumer ethnocentrism and test } \\
\text { the effects of animosity and } \\
\text { consumer ethnocentrism on the } \\
\text { purchase of foreign products. }\end{array}$ & $\begin{array}{l}\text { A survey of } \\
600 \text { Chinese } \\
\text { consumers. }\end{array}$ & $\begin{array}{l}\text { Both animosity and consumer ethnocentrism nega- } \\
\text { tively affect the willingness to buy foreign (Japa- } \\
\text { nese or U.S.) products. Chinese consumer ethno- } \\
\text { centrism is a combination of patriotism and nega- } \\
\text { tive internationalism. Patriotism is positively corre- } \\
\text { lated with consumer ethnocentrism but is negatively } \\
\text { correlated with animosity. }\end{array}$ \\
\hline $\begin{array}{l}\text { Rose, Rose, } \\
\text { and Shoham } \\
\text { (2009) }\end{array}$ & $\begin{array}{l}\text { To examine sub-cultural animosity } \\
\text { attitudes of individuals from one } \\
\text { nation toward the products of other } \\
\text { nations. }\end{array}$ & $\begin{array}{l}\text { A survey } \\
\text { among } 112 \\
\text { Arab Israeli } \\
\text { and } 111 \\
\text { Jewish } \\
\text { Israeli } \\
\text { consumers. }\end{array}$ & $\begin{array}{l}\text { Animosity and consumer ethnocentrism lead to a } \\
\text { decreased willingness to buy a foreign nation's } \\
\text { products. Different cultural sub-groups feel } \\
\text { different levels of animosity to foreign nation's } \\
\text { products. }\end{array}$ \\
\hline $\begin{array}{l}\text { Funk, D. Ar- } \\
\text { thurs, Trevino, } \\
\text { and Joireman } \\
(2010)\end{array}$ & $\begin{array}{l}\text { To research consumer animosity } \\
\text { concerning the 'hybrid' products. }\end{array}$ & $\begin{array}{l}\text { An online } \\
\text { survey of } \\
319 \\
\text { American } \\
\text { consumers. }\end{array}$ & $\begin{array}{l}\text { Consumers' willingness to purchase a complex } \\
\text { hybrid product is negatively affected by partial } \\
\text { production shifts to an animosity-evoking country. } \\
\text { Self-reported animosity predicts lower willingness } \\
\text { to purchase above and beyond consumer } \\
\text { ethnocentrism and perceived product quality. }\end{array}$ \\
\hline $\begin{array}{l}\text { Huang, Phau, } \\
\text { and Lin (2010) }\end{array}$ & $\begin{array}{l}\text { To investigate the effects of } \\
\text { consumer animosity in the context } \\
\text { of the boycott of Australian } \\
\text { consumers against French products } \\
\text { in the light of French nuclear tests } \\
\text { in Pacific region. }\end{array}$ & $\begin{array}{l}\text { A survey } \\
\text { among } 456 \\
\text { respondents. }\end{array}$ & $\begin{array}{l}\text { Perceived economic hardship and normative influ- } \\
\text { ence of members of a consumers' reference group } \\
\text { have a positive impact on consumer animosity, } \\
\text { which, in turn, negatively affects willingness to } \\
\text { buy. }\end{array}$ \\
\hline $\begin{array}{l}\text { Maher and } \\
\text { Mady } \\
(2010)\end{array}$ & $\begin{array}{l}\text { To examine the roles of anticipated } \\
\text { emotions and subjective norms on } \\
\text { consumers' purchase intentions in } \\
\text { the context of animosity, as well as } \\
\text { the influence of group responsibil- } \\
\text { ity on animosity. }\end{array}$ & $\begin{array}{l}\text { A survey of } \\
447 \\
\text { undergraduat } \\
\text { e students } \\
\text { using } \\
\text { snowball } \\
\text { sampling } \\
\text { technique. }\end{array}$ & $\begin{array}{l}\text { Subjective norms - as well as the negative emotions } \\
\text { expected from buying the product and the positive } \\
\text { emotions expected from not buying the product - } \\
\text { lead to less willingness to buy foreign products. } \\
\text { Social pressure is a more important factor in } \\
\text { consumers' willingness to buy compared to } \\
\text { anticipated emotions. }\end{array}$ \\
\hline $\begin{array}{l}\text { Hoffmann, } \\
\text { Mai, and } \\
\text { Smirnova } \\
(2011)\end{array}$ & $\begin{array}{l}\text { To create a multidimensional and } \\
\text { universal scale to measure } \\
\text { animosity. }\end{array}$ & $\begin{array}{l}\text { A survey } \\
\text { among } 211 \\
\text { students and } \\
\text { alumni. } \\
\end{array}$ & $\begin{array}{l}\text { The consumer animosity multidimensional scale is } \\
\text { based on three universal drivers: perceived threat, } \\
\text { antithetical political attitudes, and negative personal } \\
\text { experiences. }\end{array}$ \\
\hline
\end{tabular}




\begin{tabular}{ll}
\hline $\begin{array}{l}\text { Nes, Yelker, } \\
\text { and Silkoset }\end{array}$ & $\begin{array}{l}\text { To develop the animosity theory in } \\
\text { three areas: construct domain, the } \\
\text { (2012) }\end{array}$ \\
& $\begin{array}{l}\text { mediating role of affect and model } \\
\text { testing. }\end{array}$
\end{tabular}

\begin{tabular}{ll}
\hline Fernández- & To investigate the antecedents and \\
Ferrín, Bande- & consequences of animosity and \\
Vilela, Klein, & ethnocentrism within a single \\
and Río- & model \\
Araújo (2015) &
\end{tabular}
A survey
among 210
American
and 363
Norwegian
consumers.

Animosity is a four-dimensional construct, which impacts buying behavior through affect.

$\begin{array}{ll}\text { Interviews } & \text { Consumer ethnocentrism and animosity have } \\ \text { of } 248 & \text { unique antecedents and consequences } \\ \text { consumers } & \end{array}$

\begin{tabular}{llll}
\hline Harmeling, & To examine the mediational role of & A survey of & Agonistic emotions are related to negative word of \\
Magnusson, & emotions affecting consumer & 283 Chinese & mouth and product avoidance, but not product \\
and Singh & animosity. & and 308 & quality judgment. Retreat emotions are related to \\
$(2015)$ & & $\begin{array}{l}\text { American } \\
\text { consumers. }\end{array}$ & $\begin{array}{l}\text { product avoidance and product quality judgment, } \\
\text { but not the negative word of mouth. }\end{array}$
\end{tabular}

\begin{tabular}{|c|c|c|c|}
\hline $\begin{array}{l}\text { Gineikiene } \\
\text { and Diamanto- } \\
\text { poulos } \\
(2017)\end{array}$ & $\begin{array}{l}\text { To simultaneously consider the } \\
\text { negative impact of animosity and } \\
\text { the positive impact of nostalgia on } \\
\text { product ownership in historically } \\
\text { connected markets (HCMs). }\end{array}$ & $\begin{array}{l}\text { A survey of } \\
417 \\
\text { consumers } \\
\text { in Lithuania } \\
\text { and } 414 \\
\text { consumers } \\
\text { in Ukraine. }\end{array}$ & $\begin{array}{l}\text { Nostalgia can compensate for the negative effects } \\
\text { of animosity on product judgment and product } \\
\text { ownership in HCMs with intense negative past } \\
\text { events. In contrast, in HCMs experiencing current/ } \\
\text { recent negative events animosity is a stronger } \\
\text { predictor of product judgment and ownership than } \\
\text { nostalgia. }\end{array}$ \\
\hline $\begin{array}{l}\text { Han } \\
(2017)\end{array}$ & $\begin{array}{l}\text { To investigate the impact of } \\
\text { individualism/collectivism on } \\
\text { consumer animosity. }\end{array}$ & $\begin{array}{l}\text { A survey } \\
\text { among } 304 \\
\text { Korean } \\
\text { consumers. }\end{array}$ & $\begin{array}{l}\text { Individualism/collectivism can precede consumer } \\
\text { animosity and also moderate the effects of consum- } \\
\text { er animosity on purchase intentions. }\end{array}$ \\
\hline $\begin{array}{l}\text { Heinberg } \\
\text { (2017) }\end{array}$ & $\begin{array}{l}\text { To investigate if outbreaks of } \\
\text { animosity against the West benefit } \\
\text { Chinese brands by raising } \\
\text { consumers' willingness to pay and } \\
\text { willingness to buy. }\end{array}$ & $\begin{array}{l}\text { A survey } \\
\text { among } 244 \\
\text { Chinese } \\
\text { students and } \\
\text { experiment } \\
\text { with } 676 \\
\text { Chinese } \\
\text { students }\end{array}$ & $\begin{array}{l}\text { After an outbreak of animosity, animosity against } \\
\text { the West increases Chinese consumers' willingness } \\
\text { to buy local products and willingness to pay. }\end{array}$ \\
\hline $\begin{array}{l}\text { Park and Yoon } \\
\text { (2017) }\end{array}$ & $\begin{array}{l}\text { To examine the effect of cosmopol- } \\
\text { itanism, consumer ethnocentrism, } \\
\text { and susceptibility to normative in- } \\
\text { fluence on consumer animosity and } \\
\text { the moderating role of product in- } \\
\text { volvement on purchase intentions. }\end{array}$ & $\begin{array}{l}\text { A survey } \\
\text { among } 195 \\
\text { consumers. }\end{array}$ & $\begin{array}{l}\text { Consumer ethnocentrism and susceptibility to } \\
\text { normative influence have a positive relationship } \\
\text { with animosity, while cosmopolitanism has a } \\
\text { negative relationship with animosity. Animosity } \\
\text { negatively influences intentions to purchase for } \\
\text { high-involvement products, but not for low- } \\
\text { involvement products. }\end{array}$ \\
\hline
\end{tabular}


APPENDIX II: Constructs, scale items, and sources

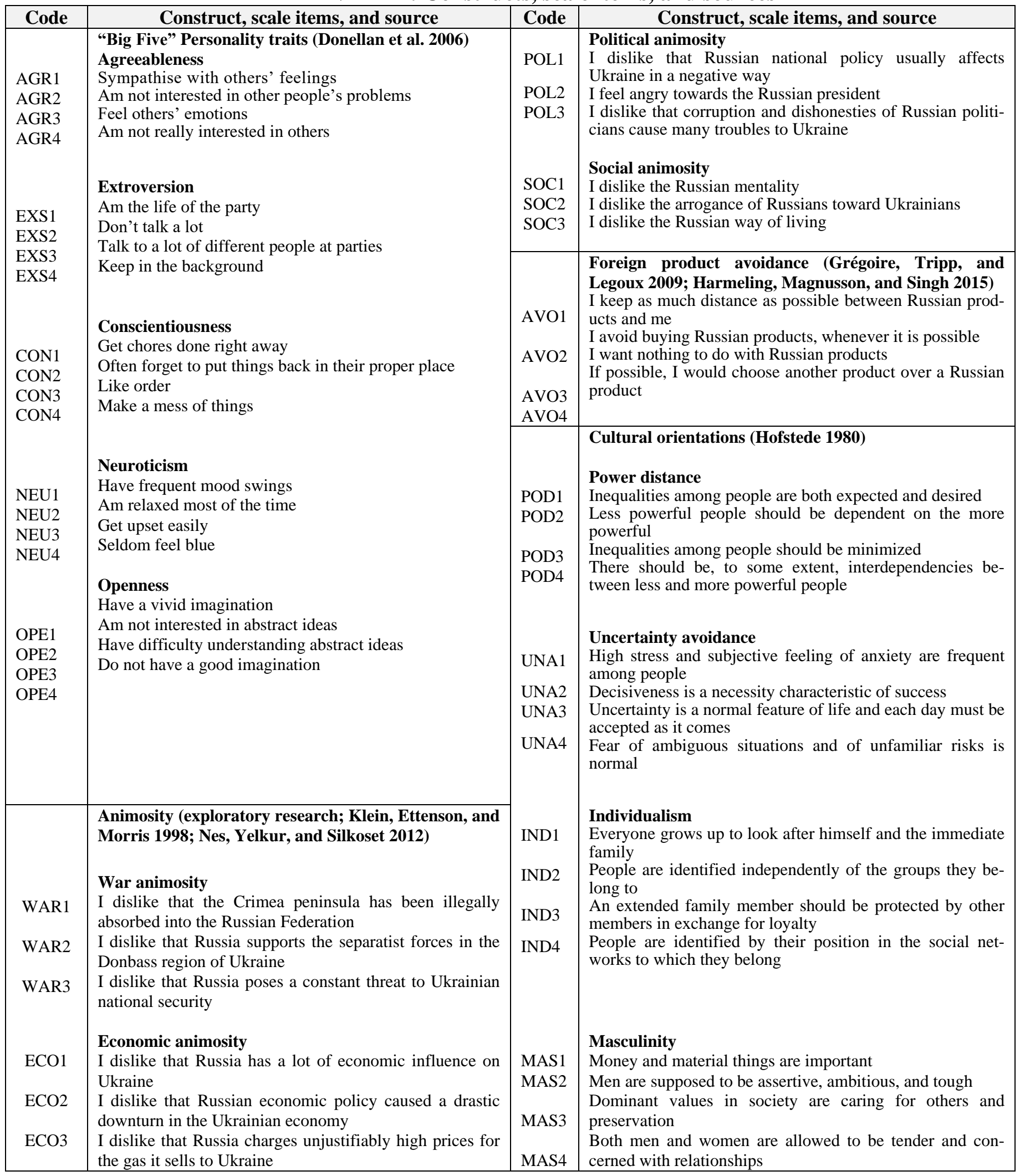


Figure 1. The Conceptual Model

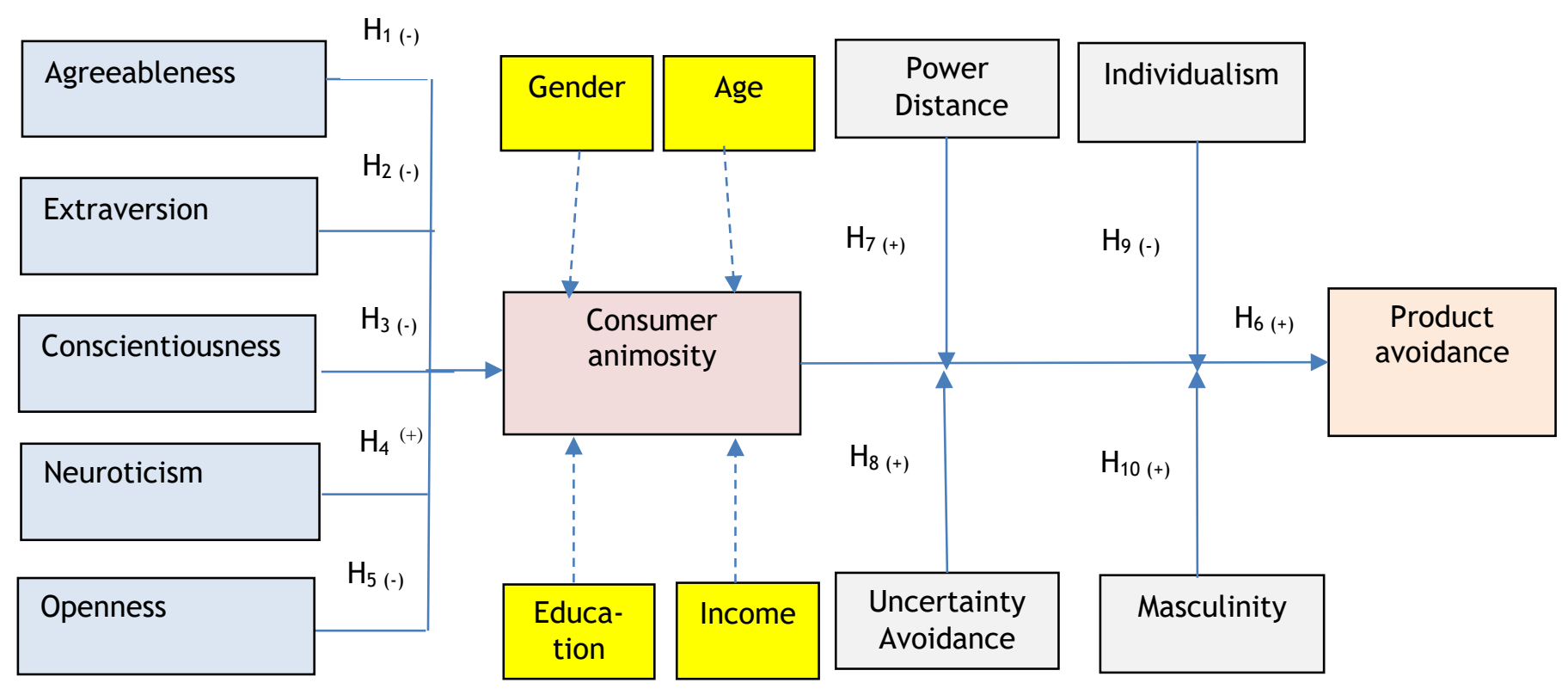


Table 1 Correlation matrix

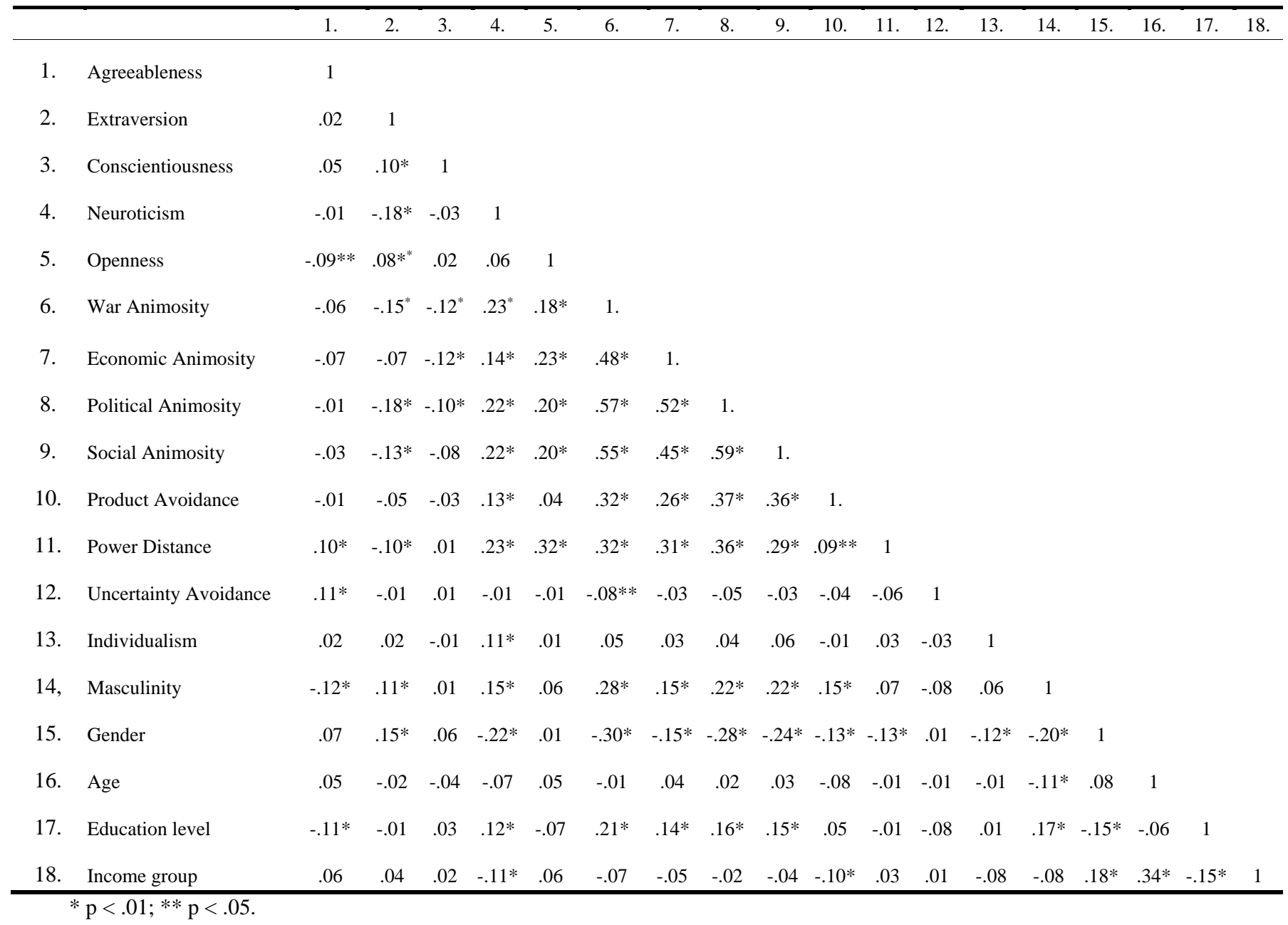


Table 2: Measurement model - Summary of construct measurement

MODEL A

\begin{tabular}{|c|c|c|c|c|c|c|c|c|c|c|}
\hline Constructs & $\begin{array}{l}\text { Scale } \\
\text { items }\end{array}$ & $\begin{array}{c}\text { Standardised } \\
\text { loadings }\end{array}$ & t-value & $\alpha$ & $\rho$ & AVE & $\begin{array}{l}\text { Mean } \\
\text { score }\end{array}$ & $\begin{array}{c}\text { Std } \\
\text { deviation }\end{array}$ & $\begin{array}{l}\text { Items } \\
\text { means }\end{array}$ & $\begin{array}{l}\text { Items } \\
\text { St.D. }\end{array}$ \\
\hline \multirow[t]{4}{*}{ Agreeableness } & AGR1 & .83 & * & \multirow[t]{4}{*}{0.88} & \multirow[t]{4}{*}{0.82} & \multirow[t]{4}{*}{0.67} & \multirow[t]{4}{*}{3.59} & \multirow[t]{4}{*}{0.98} & 3.61 & 1.18 \\
\hline & AGR2 & .66 & 16.71 & & & & & & 3.87 & 1.02 \\
\hline & AGR3 & .90 & 24.90 & & & & & & 3.50 & 1.21 \\
\hline & AGR4 & .86 & 23.76 & & & & & & 3.41 & 1.21 \\
\hline \multirow{4}{*}{ Extraversion } & EXS1 & .71 & $*$ & \multirow{4}{*}{0.84} & \multirow[t]{4}{*}{0.74} & \multirow{4}{*}{0.51} & \multirow[t]{4}{*}{3.51} & \multirow[t]{4}{*}{0.83} & 3.34 & 0.97 \\
\hline & EXS2 & .70 & 12.64 & & & & & & 3.60 & 1.12 \\
\hline & EXS3 & .74 & 13.04 & & & & & & 3.37 & 1.08 \\
\hline & EXS4 & .70 & 12.64 & & & & & & 3.74 & 1.07 \\
\hline \multirow[t]{3}{*}{ Conscientiousness } & CON1 & .68 & $*$ & \multirow[t]{3}{*}{0.73} & \multirow[t]{3}{*}{0.71} & \multirow[t]{3}{*}{0.54} & \multirow[t]{3}{*}{3.08} & \multirow[t]{3}{*}{0.88} & 2.81 & 1.05 \\
\hline & CON2 & .75 & 8.70 & & & & & & 3.20 & 1.18 \\
\hline & CON4 & .77 & 8.80 & & & & & & 3.22 & 1.15 \\
\hline \multirow[t]{4}{*}{ Neuroticism } & NEU1 & .70 & $*$ & \multirow[t]{4}{*}{0.79} & \multirow[t]{4}{*}{0.74} & \multirow[t]{4}{*}{0.51} & \multirow[t]{4}{*}{2.65} & \multirow[t]{4}{*}{0.96} & 2.89 & 1.23 \\
\hline & NEU2 & .64 & 12.16 & & & & & & 2.55 & 1.24 \\
\hline & NEU3 & .84 & 13.93 & & & & & & 2.73 & 1.30 \\
\hline & NEU4 & .64 & 12.26 & & & & & & 2.41 & 1.15 \\
\hline \multirow[t]{4}{*}{ Openness } & OPE1 & .73 & $*$ & 0.76 & 0.73 & 0.50 & 3.36 & 0.82 & 3.69 & 1.02 \\
\hline & OPE2 & .69 & 10.85 & & & & & & 3.83 & 1.08 \\
\hline & OPE3 & .68 & 10.79 & & & & & & 2.98 & 1.17 \\
\hline & OPE4 & .71 & 11.05 & & & & & & 2.95 & 1.29 \\
\hline${ }^{a}$ Consumer Animosi & & & & & & & & & & \\
\hline War Animosity & WAR1 & .88 & $*$ & 0.93 & 0.85 & 0.81 & 4.04 & 1.24 & 4.14 & 1.34 \\
\hline & WAR2 & .88 & 29.14 & & & & & & 4.17 & 1.23 \\
\hline & WAR3 & .94 & 33.27 & & & & & & 3.80 & 1.40 \\
\hline Economic Animosity & ECO1 & .69 & $*$ & 0.77 & 0.71 & 0.55 & 3.35 & 0.97 & 3.42 & 1.13 \\
\hline & $\mathrm{ECO} 2$ & .75 & 11.03 & & & & & & 3.13 & 1.27 \\
\hline & $\mathrm{ECO} 3$ & .79 & 11.25 & & & & & & 3.51 & 1.23 \\
\hline Political Animosity & POL1 & .88 & $*$ & 0.88 & 0.80 & 0.72 & 3.51 & 1.27 & 3.72 & 1.34 \\
\hline & POL2 & .81 & 24.76 & & & & & & 3.42 & 1.53 \\
\hline & POL3 & .85 & 27.15 & & & & & & 3.39 & 1.35 \\
\hline Social Animosity & SOC1 & .77 & $*$ & 0.84 & 0.76 & 0.64 & 3.47 & 1.11 & 3.15 & 1.33 \\
\hline & SOC2 & .80 & 19.58 & & & & & & 3.50 & 1.29 \\
\hline & SOC3 & .82 & 20.37 & & & & & & 3.77 & 1.22 \\
\hline Product Avoidance & AVO1 & .87 & $*$ & 0.95 & 0.89 & 0.83 & 2.98 & 1.68 & 2.99 & 1.81 \\
\hline & AVO2 & .97 & 36.61 & & & & & & 2.91 & 1.77 \\
\hline & AVO3 & .84 & 27.10 & & & & & & 3.09 & 1.83 \\
\hline & AVO4 & .95 & 35.48 & & & & & & 2.91 & 1.78 \\
\hline
\end{tabular}

${ }^{\text {a }}$ Higher-order factor $($ Mean $=3.59, \mathrm{StD}=1.03), *$ Item fixed to set the scale

Fit statistics: $\chi^{2}=1193.75, \mathrm{p}=.000, \mathrm{df}=535 ; \mathrm{NFI}=.95 ; \mathrm{NNFI}=.96 ; \mathrm{CFI}=.97$; RMSEA $=.048,90 \%$ C.I. $=(.045$, .052 ) 


\section{MODEL B}

\begin{tabular}{|c|c|c|c|c|c|c|c|c|c|c|}
\hline Constructs & $\begin{array}{l}\text { Scale } \\
\text { items }\end{array}$ & $\begin{array}{l}\text { Standardised } \\
\text { loadings }\end{array}$ & t-value & $\alpha$ & $\mathrm{P}$ & AVE & $\begin{array}{l}\text { Mean } \\
\text { score }\end{array}$ & $\begin{array}{c}\text { Std } \\
\text { deviat } \\
\text { ion }\end{array}$ & $\begin{array}{l}\text { Items } \\
\text { means }\end{array}$ & $\begin{array}{l}\text { Items } \\
\text { St.D. }\end{array}$ \\
\hline \multirow[t]{4}{*}{ Power Distance } & PDI1 & .86 & * & \multirow[t]{4}{*}{0.87} & \multirow[t]{4}{*}{0.81} & \multirow[t]{4}{*}{0.64} & \multirow[t]{4}{*}{3.33} & \multirow[t]{4}{*}{1.05} & 3.45 & 1.19 \\
\hline & PDI2 & .87 & 23.58 & & & & & & 3.20 & 1.29 \\
\hline & PDI3 & .80 & 21.15 & & & & & & 3.37 & 1.24 \\
\hline & PDI4 & .64 & 15.76 & & & & & & 3.29 & 1.24 \\
\hline Uncertainty & UAV1 & .64 & $*$ & \multirow[t]{4}{*}{0.79} & \multirow[t]{4}{*}{0.74} & \multirow[t]{4}{*}{0.52} & \multirow[t]{4}{*}{2.37} & \multirow[t]{4}{*}{0.45} & 2.64 & 1.10 \\
\hline \multirow{3}{*}{ Avoidance } & UAV2 & .68 & 8.55 & & & & & & 2.31 & 0.96 \\
\hline & UAV3 & .76 & 9.76 & & & & & & 2.20 & 1.00 \\
\hline & UAV4 & .77 & 9.78 & & & & & & 2.31 & 1.04 \\
\hline \multirow[t]{4}{*}{ Individualism } & IND1 & .67 & $*$ & \multirow{4}{*}{0.77} & \multirow{4}{*}{0.73} & \multirow[t]{4}{*}{0.51} & \multirow[t]{4}{*}{2.74} & \multirow[t]{4}{*}{0.49} & 2.70 & 1.10 \\
\hline & IND2 & .64 & 8,17 & & & & & & 2.70 & 1.09 \\
\hline & IND3 & .76 & 9.95 & & & & & & 2.67 & 1.12 \\
\hline & IND4 & .72 & 9.07 & & & & & & 2.91 & 1.16 \\
\hline \multirow[t]{4}{*}{ Masculinity } & MAS1 & .62 & $*$ & \multirow[t]{4}{*}{0.79} & \multirow[t]{4}{*}{0.76} & \multirow[t]{4}{*}{0.53} & \multirow[t]{4}{*}{3.90} & \multirow[t]{4}{*}{0.75} & 3.86 & 0.94 \\
\hline & MAS2 & .86 & 11.19 & & & & & & 3.77 & 0.97 \\
\hline & MAS3 & .75 & 10.93 & & & & & & 3.84 & 1.06 \\
\hline & MAS4 & .66 & 10.22 & & & & & & 4.15 & 0.88 \\
\hline
\end{tabular}

* Item fixed to set the scale

Fit statistics: $\chi^{2}=196.83, \mathrm{p}=.000, \mathrm{df}=98 ; \mathrm{NFI}=.94 ; \mathrm{NNFI}=.95 ; \mathrm{CFI}=.96 ;$ RMSEA $=.058,90 \%$ C.I $=(.053$, $.062)$ 
Table 3: Structural Model Results

\begin{tabular}{|c|c|c|c|c|}
\hline $\begin{array}{l}\text { Hypo- } \\
\text { thesis }\end{array}$ & Hypothesized path & $\begin{array}{c}\text { Standardized } \\
\text { path } \\
\text { coefficients }\end{array}$ & $\begin{array}{c}t- \\
\text { value }\end{array}$ & $\begin{array}{c}p- \\
\text { value }\end{array}$ \\
\hline & Main Effects & & & \\
\hline $\mathrm{H}_{1}$ & Agreeableness $\rightarrow$ Consumer Animosity & -.03 & -0.53 & .58 \\
\hline $\mathrm{H}_{2}$ & Extraversion $\rightarrow$ Consumer Animosity & -.15 & -3.14 & .00 \\
\hline $\mathrm{H}_{3}$ & Conscientiousness $\rightarrow$ Consumer Animosity & -.13 & -2.63 & .01 \\
\hline $\mathrm{H}_{4}$ & Neuroticism $\rightarrow$ Consumer Animosity & .23 & 4.81 & .00 \\
\hline $\mathrm{H}_{5}$ & Openness $\rightarrow$ Consumer Animosity & .28 & 5.20 & .00 \\
\hline \multirow[t]{2}{*}{$\mathrm{H}_{6}$} & Consumer Animosity $\rightarrow$ Product Avoidance & .35 & 8.46 & .00 \\
\hline & Moderation Effects & & & \\
\hline \multirow[t]{2}{*}{$\mathrm{H}_{7}$} & Power Distance $\rightarrow$ Product Avoidance & .08 & 1.86 & .06 \\
\hline & Consumer Animosity x Power Distance $\rightarrow$ Product Avoidance & .12 & 2.78 & .01 \\
\hline \multirow[t]{2}{*}{$\mathrm{H}_{8}$} & Uncertainty Avoidance $\rightarrow$ Product Avoidance & .04 & 0.85 & .40 \\
\hline & Consumer Animosity x Uncertainty Avoidance $\rightarrow$ Product Avoidance & .14 & 3.35 & .00 \\
\hline \multirow[t]{2}{*}{$\mathrm{H}_{9}$} & Individualism $\rightarrow$ Product Avoidance & -.09 & -1.95 & .05 \\
\hline & Consumer Animosity x Individualism $\rightarrow$ Product Avoidance & -.18 & -4.46 & .00 \\
\hline \multirow[t]{7}{*}{$\mathrm{H}_{10}$} & Masculinity $\rightarrow$ Product Avoidance & .04 & 0.63 & .53 \\
\hline & Consumer Animosity x Masculinity $\rightarrow$ Product Avoidance & .14 & 3.30 & .00 \\
\hline & Control Effects & & & \\
\hline & Gender $\rightarrow$ Consumer Animosity & -.40 & -4.45 & .00 \\
\hline & Age $\rightarrow$ Consumer Animosity & .18 & 0.61 & .54 \\
\hline & Education level $\rightarrow$ Consumer Animosity & .16 & 3.95 & .00 \\
\hline & Income group $\rightarrow$ Consumer Animosity & .07 & 0.42 & .68 \\
\hline
\end{tabular}

Fit statistics: $\chi^{2}=1245.38, \mathrm{p}=.000, \mathrm{df}=550 ; \mathrm{NFI}=.94 ; \mathrm{NNFI}=.96 ; \mathrm{CFI}=.97 ; \mathrm{RMSEA}=.049,90 \%$ C.I $=(.046$, .052 ) 